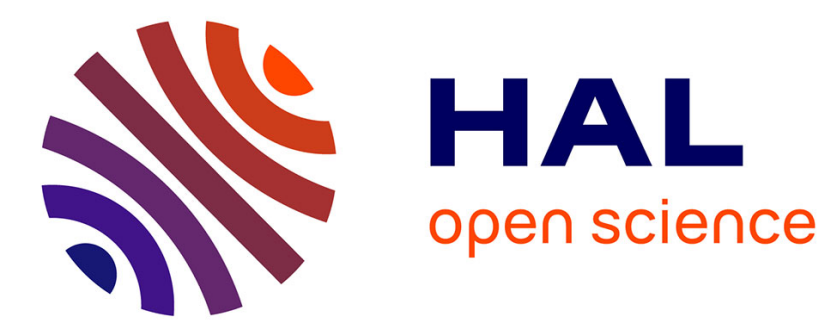

\title{
"Missing links" for the long-lived Macdonald and Arago hotspots, South Pacific Ocean
}

L Buff, M G Jackson, K Konrad, J G Konter, M. Bizimis, A Price, Estelle F. Rose-Koga, J. Blusztajn, A. A. P. Koppers

\section{- To cite this version:}

L Buff, M G Jackson, K Konrad, J G Konter, M. Bizimis, et al.. "Missing links" for the longlived Macdonald and Arago hotspots, South Pacific Ocean. Geology, 2021, 49 (5), pp.541-544. 10.1130/G48276.1 . hal-03026749v2

\section{HAL Id: hal-03026749 \\ https://hal.science/hal-03026749v2}

Submitted on 8 Oct 2021

HAL is a multi-disciplinary open access archive for the deposit and dissemination of scientific research documents, whether they are published or not. The documents may come from teaching and research institutions in France or abroad, or from public or private research centers.
L'archive ouverte pluridisciplinaire HAL, est destinée au dépôt et à la diffusion de documents scientifiques de niveau recherche, publiés ou non, émanant des établissements d'enseignement et de recherche français ou étrangers, des laboratoires publics ou privés. 


\section{1 "Missing links" for the long-lived Macdonald and Arago}

\section{2 hotspots, South Pacific Ocean}

3 L. Buff ${ }^{1 *}$, M.G. Jackson ${ }^{1}$, K. Konrad ${ }^{2,3}$ J.G. Konter ${ }^{4}$, M. Bizimis ${ }^{5}$, A. Price ${ }^{1}$, E.F. Rose-

4 Koga $^{6}$, J. Blusztajn ${ }^{7}$, A.A.P. Koppers ${ }^{3}$

$5{ }^{1}$ Department of Earth Science, University of California, Santa Barbara, 93106, USA

6 (*corresponding author: lbuff@ucsb.edu)

$7 \quad 2$ Department of Geoscience, University of Nevada, Las Vegas, NV 89154, USA.

$8 \quad{ }^{3}$ College of Earth, Ocean, and Atmospheric Sciences, Corvallis OR, 97331

$9{ }^{4}$ Department of Earth Sciences, University of Hawaii Manoa, Honolulu, HI 96822, USA

$10{ }^{5}$ School of the Earth, Ocean and Environment, University of South Carolina, Columbia, SC,

11 29208, USA

$12{ }^{6}$ Université Clermont Auvergne, CNRS, IRD, OPGC, Laboratoire Magmas et Volcans, F-63000

13 Clermont-Ferrand, France

$14{ }^{7}$ Department of Marine Chemistry, Woods Hole Oceanographic Institution, Woods Hole,

15 Massachusetts, 02543, USA

16

17

18 ABSTRACT

19 The Cook-Austral volcanic lineament extends from Macdonald seamount (east) to Aitutaki

20 Island (west), and comprises hotspot-related volcanic islands, seamounts, and atolls. The Cook-

21 Australs have been characterized as multiple overlapping, age-progressive hotspot tracks

22 generated by at least two mantle plumes, including the Arago and Macdonald plumes, which have

23 fed volcano construction for $\sim 20 \mathrm{~m}$.y. The Arago and Macdonald hotspot tracks are argued to have 
24 been active for at least 70 m.y., and to extend northwest of the Cook-Australs into the Cretaceous-

25 aged Tuvalu-Gilbert and Tokelau Island chains, respectively. Large gaps in sampling exist along

26 the predicted hotspot tracks, complicating efforts seeking to show that the Arago and Macdonald

27 hotspots have been continuous, long-lived sources of hotspot volcanism back into the Cretaceous.

28 We present new major and trace element concentrations, and radiogenic isotopes for three

29 seamounts (Moki, Malulu, Dino) and one atoll (Rose), and new clinopyroxene ${ }^{40} \mathrm{Ar} /{ }^{39} \mathrm{Ar}$ ages for

30 Rose $(24.81 \pm 1.02 \mathrm{Ma})$ and Moki $(44.53 \pm 10.05 \mathrm{Ma})$. All volcanoes are located in the poorly

31 sampled region between the younger Cook-Austral and the older, Cretaceous portions of the Arago

32 and Macdonald hotspot tracks. Absolute plate motion modeling indicates that the Rose and Moki

33 volcanoes lie on or near the reconstructed traces of the Arago and Macdonald hotspots,

34 respectively, and the the ${ }^{40} \mathrm{Ar} /{ }^{39} \mathrm{Ar}$ ages for Rose and Moki align with the predicted age progression

35 for the Arago (Rose) and Macdonald (Moki) hotspots, thereby linking the younger Cook-Austral

36 and older Cretaceous portions of the long-lived ( $>70$ m.y.) Arago and Macdonald hotspot tracks.

\section{INTRODUCTION}

39 Intraplate volcanism is thought to result from buoyantly upwelling mantle plumes that partially

40 melt beneath a moving plate, thereby producing age-progressive "hotspot" volcanism (e.g.,

41 Morgan, 1971). Some plume-derived volcanic chains, such as the Hawaii-Emperor (North Pacific)

42 and Louisville (South Pacific) chains, are well-defined with clear age progressions extending back

43 to $\sim 80 \mathrm{Ma}$ (Sharp and Clague, 2006; O'Connor et al., 2013; Koppers et al., 2012). The Cook-

44 Austral volcanic lineament in the South Pacific Ocean (Cook-Austral hereafter) is the

45 manifestation of at least two overlapping hotspot tracks - the Arago (also referred to as "Rurutu",

46 or "Atiu trend") and Macdonald hotspot tracks. Denser sampling may reveal that not all seamounts 
47 along the predicted path of the Cook-Austral hotspots relate to these hotspots, but samples from

48 two seamounts presented in this study strengthen hotspot age progressions anchored by young

49 volcanism at Macdonald and Arago seamounts, respectively (Figure 1; Turner and Jarrard, 1982;

50 Chauvel et al., 1997; Bonneville et al., 2002; Finlayson et al., 2018; Konrad et al., 2018; Rose and

51 Koppers, 2019). While Cook-Austral volcanism has been argued to be relatively short-lived (0-20

52 m.y.; Chauvel et al., 1997; Lassiter et al., 2003), there is growing evidence that the mantle plumes

53 responsible for Cook-Austral volcanism are long-lived features responsible for generating Pacific

54 seamounts during the Cretaceous (Staudigel et al., 1991; Koppers et al., 2001; 2003; 2007; Konter

55 et al., 2008; Finlayson et al., 2018; Konrad et al., 2018).

56 Using absolute plate motion models, Koppers et al. (2003; 2007) and Konter et al. (2008)

57 showed that Cretaceous Pacific island chains, including the Tokelau and Tuvalu-Gilbert chains,

58 were located over the Macdonald and Arago mantle plumes, respectively (Figure 1). Konter et al.

59 (2008) also showed geochemical similarities between the Cretaceous and Cook-Austral portions

60 of these two hotspot tracks, strengthening the link between the younger and older segments of

61 these hotspot tracks. Recently, Finlayson et al. (2018) and Konrad et al. (2018) showed that the

62 Tuvalu chain captures the $50 \mathrm{Ma}$ "bend" (temporally and morphologically similar to the Hawaii-

63 Emperor Bend) of the proposed Arago hotspot, thereby strengthening the link between the younger

64 Cook-Austral and older Cretaceous segments of this proposed long-lived hotspot. However, 65 volcanoes sampling the 10-45 Ma portion of the Arago hotspot represent an uncharacterized gap

66 in the hotspot track. In contrast to the Arago hotspot, the Hawaii-Emperor Bend portion of the

67 proposed Macdonald hotspot track has not yet been identified, and it will be important for linking

68 the more recent Cook-Austral and older Cretaceous Tokelau segments of this hotspot track. Thus,

69 while there is growing evidence that the Macdonald and Arago hotspots have been active since at 
70 least $\sim 70 \mathrm{Ma}$, critical gaps in sampling and characterization of these two hotspot tracks weaken

71 the hypothesis for long-lived, continuous volcanism.

72 Volcanoes in the region of the Samoan hotspot track, located $\sim 1,000 \mathrm{~km}$ WNW of Aitutaki

73 Island, were found to exhibit geochemical signatures inconsistent with nearby Samoan volcanoes

74 (Jackson et al., 2010). Termed "interlopers" (i.e., not belonging in the region: Jackson et al. 2010),

75 these volcanoes (Rose atoll and two seamounts, Malulu and Papatua) yielded samples exhibiting

76 significant alteration and thick ferromanganese coatings, which contrast with the young, fresh

77 lavas from Samoan volcanoes in the region. These interloper volcanoes also exhibit geochemical

78 signatures consistent with an origin over Cook-Austral hotspots, which lie on, or close to, the

79 reconstructed Macdonald and Arago hotspot traces.

80 We targeted the region between the Samoan hotspot and the Cook-Australs for additional

81 sampling on the NOAA ocean exploration cruise EX1702 aboard the Okeanos Explorer in

82 February/March 2017. Four volcanoes were sampled (Rose atoll and Malulu, Moki, and Dino

83 seamount) by ROV (Remotely Operated Vehicle; Figure 1; Tables S1 and S2 in the

84 Supplemental Material ${ }^{1}$ ). Descriptions and thin section images are publicly available for all

85 EX1702 samples used in this study (osu-mgr.org/noaa-ex1702). We present new Sr-Nd-Pb-Hf

86 isotopic data (Figures 2, S1) and major and trace element concentrations (Figure S2) on these

87 volcanoes. The new geochemical and geochronological data, in conjunction with previously

88 published geochemical data for two legacy samples from Rose atoll and one legacy sample each

89 for Malulu and Papatua seamounts (obtained by deep-sea dredging; see Supplemental Materials

90 and Jackson et al. (2010)), show that the Moki and Rose volcanoes provide "missing links"

91 between younger Cook-Austral and older Cretaceous segments of the Macdonald and Arago 
92 hotspots, respectively. These links extend the longevity of the Arago and Macdonald hotspots to

93 at least $70 \mathrm{Ma}$, making them two of the longest-lived hotspots in the Pacific.

95 RESULTS AND DISCUSSION

97 atoll and the Malulu, Moki, and Dino seamounts are detailed in the Supplemental Materials. Due

98 to the typically high degrees of submarine alteration, fine-grained to glass-rich groundmasses

99 and/or absence of traditionally dated phenocrystic phases (e.g. plagioclase), ages were not

100 available for whole rock samples from these five volcanoes; nonetheless, with extensive acid

101 leaching, we could obtain radiogenic isotopic compositions on these samples (see Supplemental

102 Materials). However, new advancements in ${ }^{40} \mathrm{Ar} /{ }^{39} \mathrm{Ar}$ methodology permit age determinations

103 from clinopyroxene phenocrysts (Konrad et al., 2019). Using this technique, we successfully

104 dated lava flows from the Moki and Rose volcanoes. The clinopyroxene separates from Rose 105 Atoll (sample AVON2/3-D66-1) and Moki Seamount (sample EX1702-D7-2) both produced age

106 spectrums that meet standard ${ }^{40} \mathrm{Ar} /{ }^{39} \mathrm{Ar}$ criteria, where plateaus include $>60 \%$ of the ${ }^{39} \mathrm{Ar}_{(\mathrm{K})}$ and

107 probability of fit $(\mathrm{P})$ values $>5 \%$. Two experiments for AVON2/3-D66-1, carried out on two

108 clinopyroxene size fractions, produced concordant plateaus, which allows for the results to be

109 combined and averaged (Figure S3). The ${ }^{40} \mathrm{Ar} /{ }^{36} \mathrm{Ar}$ intercept values are within uncertainty of

110 atmosphere (298.6), supporting the plateau age of $24.81 \pm 1.02 \mathrm{Ma}(2 \sigma)$. This age places Rose

111 atoll squarely on the age-progression for the Arago hotspot (Figure 3), which is consistent with

112 the observation that Rose is near the reconstructed trace of the Arago hotspot (Figure 1). Sample

113 EX1702-D7-2 contained low concentrations of potassium derived ${ }^{39} \mathrm{Ar}$ and radiogenic ${ }^{40} \mathrm{Ar}$,

114 resulting in large uncertainties. The experiment produced a long plateau with a slightly higher- 
115 than- atmospheric ${ }^{40} \mathrm{Ar} /{ }^{36} \mathrm{Ar}$ intercept value of $313 \pm 12(2 \sigma)$. Therefore, the inverse isochron age

116 determination is preferred at $44.53 \pm 10.05 \mathrm{Ma}(2 \sigma)$ (Figure S3, Tables S3,S 4). While

117 uncertainties are large, the Moki seamount age places it on the Macdonald hotspot age

118 progression (Figure 3).

119 New geochemical data are presented in Tables S1 and S2. In radiogenic isotopic space,

120 Macdonald and Arago seamounts sample HIMU (high ' $\mu$ ', or high ${ }^{238} \mathrm{U} /{ }^{204} \mathrm{~Pb}$ ), EM (enriched

121 mantle) and geochemically-depleted endmembers (Chauvel and Vidal, 1992; Chauvel et al., 1997;

122 Lassiter et al., 2003; Hanyu et al., 2013) that may reflect a contribution from a C (Common; Hanan

123 and Graham, 1996) or FOZO (Hart et al., 1992) component (Konter et al., 2008; Figures 2, S1).

124 While Rose atoll is erupted over the Arago hotspot, whole rock (Jackson et al., 2010) and glass

125 geochemistry do not consistently plot in the fields for Arago hotspot volcanoes in the Cook-Austral

126 volcanic lineament or the older portion of the Arago hotspot (Gilbert, Tuvalu, Marshall, and Wake

127 islands and seamounts), and in some isotope spaces one or multiple Rose samples plot only in the 128 field for Macdonald hotspot volcanoes (Figures 2, S1).

129 The Moki Seamount sample yielded an age with greater uncertainty, but the age is

130 nonetheless consistent with a Macdonald hotspot origin, and the Moki sample consistently falls

131 in a region of isotopic space that overlaps with Macdonald hotspot volcanoes (Figures 2, S1). In

132 the hotspot reconstruction using the Wessel and Kroenke (2008) absolute plate motion model,

133 Moki plots significantly closer to the reconstructed trace of the Macdonald hotspot track than the

134 Arago hotspot track, consistent with the geochronological and geochemical data above (Figure

135 1). While uncertainties are large, the Moki seamount age places it on the Macdonald hotspot age

136 progression (Figure 3), and the age for Moki overlaps with the reconstructed Macdonald hotspot

137 track, even at the $1 \sigma$ level. 
The Dino Seamount sample and the new Malulu Seamount sample presented here

139 (EX1702-D12-5) consistently plot in the field for Macdonald hotspot volcanoes in the Cook-

140 Austral volcanic lineament, but age data are needed before a Macdonald hotspot designation can

141 be assigned. Papatua seamount (Jackson et al., 2010) plots in a region that overlaps the Macdonald

142 and Arago hotspots in all isotopic spaces for which there are available data except for the

$143{ }^{206} \mathrm{~Pb} /{ }^{204} \mathrm{~Pb}$ vs ${ }^{143} \mathrm{Nd} /{ }^{144} \mathrm{Nd}$ isotope space where it plots in the Macdonald field (Figure 2 and Figure

$144 \mathrm{~S} 1)$. Unfortunately, Papatua is also geographically located on a portion of the reconstructed hotspot

145 tracks where the Macdonald and Arago tracks overlap, preventing a hotspot designation for

146 Papatua. Age data are needed to determine the hotspot origin of this seamount.

147 The link between the younger Cook-Austral and older Cretaceous segments of the

148 Macdonald and Arago hotspots provided by samples from Moki seamount and the Rose atoll,

149 respectively, has two key implications: 1) it allows us to posit, with greater confidence, that the

150 Macdonald hotspot is both continuous and long lived and 2) it supports previous arguments for the

151 longevity of the Arago hotspot (Finlayson et al., 2018). Thus, the Macdonald and Arago hotspots

152 join Hawaii (Tarduno et al., 2003; O’Connor et al., 2013) and Louisville (Lonsdale, 1998; Koppers

153 et al., 2012) as two Pacific hotspots whose activity has been mapped for least 70 m.y.

154 An important outcome of this work is in strengthening the case for the longevity of the

155 Arago and Macdonald hotspots. However, it is becoming increasingly clear that the Arago and

156 Macdonald hotspots show significant overlap in $\mathrm{Sr}-\mathrm{Nd}-\mathrm{Pb}-\mathrm{Hf}$ isotopic space, and it is the

157 combination of geochemistry and ages that uniquely constrains which hotspot a given seamount

158 belongs to. For example, the Arago and Macdonald plumes have consistently sampled the most

159 extreme HIMU compositions $\left({ }^{206} \mathrm{~Pb} /{ }^{204} \mathrm{~Pb}\right.$ up to 21.42 for Arago, and 21.93 for Macdonald;

160 Figure 2) in the Pacific since the Cretaceous (Konter et al., 2008; Hanyu et al., 2011; Finlayson 
161 et al., 2018). The reason for this may be due to the close proximity of the two hotspots: the long-

162 lived Arago hotspot is located just $\sim 1200 \mathrm{~km}$ WNW from the Macdonald hotspot. If both

163 hotspots are fed by mantle plumes that emerge from the core-mantle boundary, the plume

164 conduits are separated by only $\sim 660 \mathrm{~km}$ at the core mantle boundary. Thus, the regions (i.e.,

165 "feeding zones") at the core mantle boundary that are sourcing material to the upwelling

166 Macdonald and Arago plumes may overlap, explaining the similar isotopic signatures at both

167 hotspots (Figure 2). If both plumes have been producing active volcanism for $>70$ m.y., an

168 important dynamical question to be addressed is how the two closely-spaced plume conduits

169 have interacted over geologic time (Lassiter et al., 2003). Both plumes arise from the large low

170 shear-wave velocity province (LLSVP) situated on top of the core-mantle boundary beneath the

171 Pacific (Jackson et al., 2018), and long-lived HIMU signatures in both plumes might suggest this

172 is a geochemical characteristic of the region of the Pacific LLSVP that is sourced by both

173 plumes.

174

175 Acknowledgements. We acknowledge helpful reviews from Oliver Nebel and two anonymous

176 referees. We thank the NOAA Ocean Explorer program and crew of the Okeanos Explorer

177 expedition EX1702. The Oregon State University Marine and Geology Repository provided

178 samples from the EX1702 expedition. Konrad thanks D. Heaton for assistance with the age

179 determinations. Jackson acknowledges support from NSF grants OCE-1912931, EAR-1900652,

180 EAR-1429648. Rose-Koga acknowledges support from Laboratory of Excellence ClerVolc

181 (Clermont-Ferrand Centre for Volcano Research). This is Laboratory of Excellence ClerVolc

182 contribution number 438. 
Figure 1. Map of the current Cook-Austral, Tokelau, and Tuvalu-Gilbert seamounts and volcanoes (South Pacific Ocean) pertaining to this study, showing reconstructed tracks for the Samoan and Cook-Austral hotspots (including Macdonald and Arago hotspots). Shaded

189 bands anchored to the active portions of each hotspot track are reconstructed traces for each 190 hotspot track (dark blue=Macdonald, red=Arago, yellow=Rarotonga, purple=Samoa), and are 191 based on the Wessel and Kroenke (2008) absolute plate motion model; stars mark proposed 192 hotspot locations. Blue circles represent volcanoes previously associated with the Macdonald 193 hotspot and red circles represent volcanoes previously associated with the Arago hotspot (data 194 sources are from the following: Koppers et al., 2007; Konrad et al., 2018; Rose and Koppers, 195 2019; Jackson et al., 2020). The five interloper volcanoes investigated in this study-Moki, 196 Malulu, Rose, Dino, and Papatua — are also indicated in the map.

199 from Macdonald and Arago hotspot-related volcanoes. The Moki and Malulu isotopic data 200 produced for this study are from clinopyroxene phenocrysts, as seawater alteration prevented the 201 analysis of whole rock samples. New data also include pillow rim glass analyses from Rose atoll, 202 whole rock data from Dino seamount, and previously-published whole rock data on Rose, Malulu, 203 and Papatua lavas from Jackson et al. (2010). The younger portions of the Arago (red field) and 204 Macdonald (blue) hotspots in the Cook-Austral volcanic lineament are distinguished from the 205 older portions of these hotspots (light grey with long dashed lines for the Tuvalu, Gilbert, Marshall 206 and Wake islands and seamounts [i.e., Old Arago]; dark grey with short dashed lines for the 
207 Tokelau Islands and seamounts [i.e., Old Macdonald]). Age-corrected (to the time of eruption)

208 isotopic values are shown, but only where ages are available (Moki, and Rose atoll). The three

209 undated Rose samples are assumed to have the same age as sample EX1702-D3-2. The isotopic

210 shift due to the age correction is shown by the line extending from the respective datapoints (which

211 represents the magnitude and direction of the age correction). The other samples (Malulu, Papatua,

212 and Dino) are not associated with ages and age corrections are not provided. All data not produced

213 in this study was previously published and downloaded from the Georoc database

214 (http://georoc.mpch681mainz.gwdg.de/georoc). HIMU—high $\mu=$ high ${ }^{238} \mathrm{U} /{ }^{204}$;Pb; EM1-EM2—

215 enriched mantle sources. Figure is modified after Jackson et al. (2020).

216

217 Figure 3. Hotspot track age-distance plot showing Rose and Moki volcanoes (South Pacific

218 Ocean), including volcanoes associated with the Macdonald, Arago, Rarotonga, and Samoa

219 trends plotted along their respective reconstructed hotspot track. The clinopyroxene

220 incremental heating ${ }^{40} \mathrm{Ar} /{ }^{39} \mathrm{Ar}$ ages for Rose and Moki are labeled (and shown with $2 \sigma$

221 uncertainties). Great circle distances from the active hotspots are used. The Wessel and Kroenke

222 (2008) absolute plate motion model, used to model volcanic age progressions, is shown for each

223 hotspot (blue=Macdonald, red=Arago, black=Rarotonga, and pink=Samoa). Estimates for the

224 uncertainty in the Wessel and Kroenke (2008) model are also provided (dashed lines). Ages for

225 the Tokelau and Tuvalu-Gilbert volcanoes were published by Staudigel et al. (1991), Koppers et

226 al. (2003) Konter et al. (2008), Finlayson et al. (2018), and Konrad et al. (2018). Ages for the

227 Cook-Austral volcanic lineament are compiled in Jackson et al. (2020) and Rose and Koppers 228 (2019). 
$230{ }^{1}$ Supplemental Material. Methodology for the sample analyses, data tables for the radiogenic 231 isotopes, major and trace elements, and successful ${ }^{40} \mathrm{Ar} /{ }^{39} \mathrm{Ar}$ dates, and additional figures provided

232 here. Please visit https://doi.org/10.1130/XXXXX to access the supplemental material, and contact 233 editing@geosociety.org with any questions.

\section{References Cited}

237 Bonneville, A., Le Suave, R., Audin, L., Clouard, V., Dosso, L., Gillot., P.Y., Janney, P., and 238 Maamaatuaiahutapu, K., 2002, Arago Seamount: The missing hotspot found in the 239 Austral Islands. Geology, v. 30, p. 1023-1026.

241 Chauvel, C., McDonough, W., Guille, G., Maury, R., and Duncan, R., 1997, Contrasting old and young volcanism in Rurutu Island, Austral chain. Chemical Geology, v. 139, p. 125-143.

244 Chauvel, C., Hofmann, A.W., and Vidal, P., 1992, HIMU-EM: the French Polynesian connection. Earth and Planetary Science Letters, v. 110, p. 99-119.

247 Finlayson, V., Konter, J.G., Konrad, K., Koppers, A.A.P., Jackson, M.G., and Rooney, T.O., 2018, $\mathrm{Sr}-\mathrm{Pb}-\mathrm{Nd}-\mathrm{Hf}$ isotopes and ${ }^{40} \mathrm{Ar} /{ }^{39} \mathrm{Ar}$ ages reveal a Hawaii-Emperor-style bend in the Rurutu hotspot. Earth and Planetary Science Letters, v. 500, p. 168-179.

251 Hanan, B. B., Graham, W. D., 1996, Lead and Helium Isotope Evidence from Oceanic Basalts 
for a Common Deep Source of Mantle Plumes. Science, v. 272, p. 991-995, doi:

Hanyu, T., Tatsumi, Y., Senda, R., Miyazaki, T., Chang, Q., Hirahara, Y., Takahashi, T., Geochemistry, Geophysics, Geosystems, v. 12, Q0AC09.

Hanyu, T., Dosso, L., Ishizuka, O., Tani, K., Hanan, B.B., Adam, C., Nakai, S., Senda, R., Chang, Q., and Tatsumi, Y., 2013, Geochemical diversity in submarine HIMU basalts from Austral Islands, French Polynesia. Contributions to Mineralogy and Petrology, v. 166, p. $1285-1304$.

268

Hart, S. R., Hauri, E. H., Oschmann, L. A., Whitehead, J. A., 1992, Mantle Plumes and Entrainment: Isotopic Evidence. Science, v. 256, p. 517-520, doi: 10.1126/science.256.5056.517.

Jackson, M.G., Hart, S.R., Konter, J.G., Koppers, A.A.P., Staudigel, H., Kurz, M.D., Blusztajn, J., and Sinton, J.M., 2010, The Samoan hotspot track on a "hotspot highway": Implications for mantle plumes and a deep Samoan mantle source. Geochemistry, Geophysics, Geosystems, v. 11, Q12009, doi:10.1029/2010GC003232.

273

274 Jackson, M.G., Becker, T.W., Konter, J.G., 2018, Geochemistry and distribution of recycled 
domains in the mantle inferred from $\mathrm{Nd}$ and $\mathrm{Pb}$ isotopes in oceanic hot spots:

Jackson, M.G., Halldórsson, S.A., Price, A., Kurz, M.D., Konter, J.G., Koppers, A.A.P., Day, J.M.D., 2020, Contrasting old and young volcanism from Aitutaki, Cook Islands: Implications for the origins of the Cook-Austral volcanic chain. Journal of Petrology, egaa037, https://doi.org/10.1093/petrology/egaa037.

283

Konrad, K., Koppers, A.A.P., Steinberger, B., Finlayson, V., Konter, J., and Jackson, M.G., 2018, On the relative motions of long-lived Pacific mantle plumes. Nature Communications, v. 9, 854, DOI: 10.1038/s41467-018-03277-x.

291

292 Konter, J.G., Hanan, B.B., Blichert-Toft, J., Koppers, A.A.P., Plank, T., Staudigel, H., 2008, One 293 hundred million years of mantle geochemical history suggest the retiring of mantle 295

296 Koppers, A.A.P., Phipps Morgan, J., and Staudigel, H., 2001, Testing the fixed hotspot 
hypothesis using ${ }^{40} \mathrm{Ar} /{ }^{39} \mathrm{Ar}$ age progressions along seamount trails. Earth and Planetary Science Letters, v. 185, p. 237-252.

Koppers, A.A.P., Pringle, M.S., Wijbrans, J.R., 2003, Short-lived and discontinuous intraplate volcanism in the South Pacific: Hot spots or extensional volcanism? Geochemistry,

Koppers, A.A.P., Staudigel, H., Phipps Morgan, J., and Duncan, R.A., 2007, Nonlinear Geophysics, Geosystems, v. 4, 1089. ${ }^{40} \mathrm{Ar} /{ }^{39} \mathrm{Ar}$ age systematics along the Gilbert Ridge and Tokelau Seamount Trail and the timing of the Hawaii-Emperor Bend. Geochemistry, Geophysics, Geosystems, v. 8, Q06L13, doi:10.1029/2006GC001489.

Koppers, A.A.P., Yamazaki, T., Geldmacher, J., Gee, J.S., Pressling, N., Hoshi, H., Anderson,

316 Lassiter, J.C., Blichert-Toft, J., Hauri, E.H., Barsczus, H.G., 2003, Isotope and trace element L., Beier, C., Buchs, D.M., Chen, L.-H., Cohen, B.E., Deschamps, F., Dorais, M.J., Ebuna, D., Ehmann, S., Fitton, J.G., Fulton, P.M., Ganbat, E., Hamelin, C., Hanyu, T., Kalnis, L., Kell, J., Machida, S., Mahoney, J.J., Moriya, K., Nichols, A.R.L., Rausch, S., Sano, S., Sylvain, J.B., and Williams, R., 2012, Limited latitudinal mantle plume motion for the Louisville hotspot. Nature Geoscience, v. 5, p. 911-917. variations in lavas from Raivavae and Rapa, Cook-Austral islands: constraints on the nature of HIMU- and EM-mantle and the origin of mid-plate volcanism in French Polynesia. Chemical Geology, v. 202, p. 115-138. 
321 Lonsdale, P., 1988, Geography and history of the Louisville hotspot chain in the southwest Pacific. Journal of Geophysical Research, v. 93, p. 3078-3104.

323

324 Morgan, W.J., 1971, Convection Plumes in the Lower Mantle. Nature, v. 230, p. 42-43.

325

326 O'Connor, J.M., Steinberger, B., Regelous, M., Koppers, A.A.P., Wijbrans, J.R., Haase, K.M.,

327 Stoffers, P., Jokat, W., and Garbe-Schönberg, D., 2013, Constraints on past plate and

328 mantle motion from new ages for the Hawaiian-Emperor Seamount Chain. Geochemistry,

329 Geophysics, Geosystems, v. 20, p. 4756-4778. https://doi.org/10.1029/2019GC008302.

330

331 Rose, J., and Koppers, A.A.P., 2019, Simplifying age progressions within the Cook-Austral Islands using high-resolution ARGUS-VI 40Ar/39Ar incremental heating ages. Geochemistry, Geophysics, Geosystems, v. 14, p. 4564-4584.

Sharp, W.D., and Clague, D.A., 2006, 50-Ma initiation of Hawaiian-Emperor bend records major change in Pacific plate motion. Science, v. 313, p. 1281-1284.

338 Staudigel, H., Park, K.-H., Pringle, M., Rubenstone, J.L., Smith, W.H.F., and Zindler, A., 1991, Science Letters, v. 102, p. 24-44.

342 Tarduno, J.A., Duncan, R.A., Scholl, D.W., Cottrell, R.D., Steinberger, B., Thordarson, T., Kerr, 
B.C., Neal, C.R., Frey, F.A., Torii, M., and Carvallo, C., 2003, The Emperor Seamounts: Southward motion of the Hawaiian hotspot plume in Earth's mantle. Science, v. 301, p. 1064-1069.

347 Turner, D.L., and Jarrard, R.D., 1982. K/Ar dating of the Cook Austral island chain; a test of the hot spot hypothesis. Journal of Volcanology and Geothermal Research, v. 12, p. 187220.

351 Wessel, P., and Kroenke, L.W., 2008, Pacific absolute plate motion since 145Ma: an assessment of the fixed hot spot hypothesis. Journal of Geophysical Research, v.113, B06101. https://doi.org/10.1029/2007JB005499. 


\section{Supplemental Materials}

358

359

360

361

362

363

364

365

366

367

368

369

370

371

372

373

374

375

376

377

378

379

380

381

382

383

384

\section{Methods}

Sample locations, preparation and wet chemistry.

The samples in this study were collected by deep submarine dredging from four seamounts (Papatua, Moki, Seamount D ["Dino"], Malulu) and one atoll (Rose) in the Samoan region. Several samples in this study were collected during the 2017 expedition (EX1702) aboard the NOAA Okeanos Explorer: Moki seamount (basaltic sample D7-2), Dino seamount (basaltic sample D11-1), Rose atoll (pillow fragment sample D3-2), and Malulu seamount (hyaloclastite sample D12-5). Finally, two samples from the 1999 AVON2/3 expedition aboard the R/V Melville which were previously characterized are presented here with modern $\mathrm{Pb}$-isotopic analyses: AVON2/3-D67-11 from Malulu seamount which is an altered basalt, and basaltic sample AVON2/3-D66-1 from Rose atoll. Tables S1 and S2 present previously published data on these two Rose samples in addition to two other samples-AVON2/3-D65-18 (from Malulu seamount) and ALIA-DR129-05 (from Papatua seamount) - from non-Samoan seamounts in the Samoan region. Sample locations and geochemical characterization of these four previously published lavas can be found in Jackson et al. (2010).

Samples were crushed in plastic bags to avoid exposure to metal. Crushed material was then sieved. For two samples (EX1702-D12-5 hyaloclastite from Malulu seamount and EX1702D7-2 basalt from Moki seamount), clinopyroxene was removed for radiogenic isotopic work due to the lack of fresh basaltic material. For Rose atoll sample EX1702-D3-2, volcanic glass was removed from the pillow rim for radiogenic isotopic analysis (this glass was also characterized for major and trace element compositions, but we also present whole rock major and trace element data for this sample as well). For sample EX1702-11-1 (Seamount D), $200 \mathrm{mg}$ of the freshest $(0.5$ to $1 \mathrm{~mm})$ rock chips were analyzed, targeting groundmass. We also separated the freshest groundmass chips from two previously characterized lavas-AVON2/3-D66-1 (Rose atoll) and AVON2/3-D67-11 (Malulu seamount) — for a new characterization using modern $\mathrm{Pb}$ isotopic analyses and new analyses of $\mathrm{Sr}$ and $\mathrm{Nd}$ isotopes on the same material.

The groundmass samples (including the EX1702-D3-2 glass) were treated with a heavy leaching protocol described in Price et al. (2016) which, in addition to the $6 \mathrm{~N} \mathrm{HCl}$ leaching treatment, uses hot $4 \mathrm{~N} \mathrm{HNO}_{3}$ and hot $30 \% \mathrm{H}_{2} \mathrm{O}_{2}$. The clinopyroxene samples were first leached in concentrated $\mathrm{HCl}$ for 1 hour at $40^{\circ} \mathrm{C}$, then in concentrated nitric for 1 hour at $40^{\circ} \mathrm{C}$, with $\sim 1$ hour of sonication in the same acid following each leaching step; after this initial leach, the clinopyroxenes were subjected to the same "heavy leaching" as the groundmass and glass samples (and, following leaching, only pristine clinopyroxenes were selected for dissolution and analysis). Note that replicated analysis of the D11-1 groundmass followed additional leaching: it was treated with the strong leaching protocol followed by an additional 8 hours of leaching in $6 \mathrm{~N}$ $\mathrm{HCl}$ at $60^{\circ} \mathrm{C}$ and an additional 10 minutes leaching in cold concentrated HF; this may explain the offset in $\mathrm{Sr}, \mathrm{Nd}$, and $\mathrm{Pb}$ isotopes between the original and replicate rounds of analyses of this sample. USGS reference materials were not leached. Following leaching, samples were rinsed and sonicated repeatedly in MilliQ $\mathrm{H}_{2} \mathrm{O}(\geq 18.2 \mathrm{M} \Omega \cdot \mathrm{cm}$ deionized water). Sample dissolution, wet chemistry (including $\mathrm{Sr}, \mathrm{Pb}, \mathrm{Hf}$ and $\mathrm{Nd}$ elemental separations), and mass spectrometry was carried out in one of the three following institutions:

1. One batch of samples underwent $\mathrm{Sr}, \mathrm{Nd}$, and $\mathrm{Pb}$ chemical separations at UCSB, with $\mathrm{Sr}$ and Nd isotopes analyzed on the UCSB TIMS and Pb isotopes analyzed on the WHOI 
MC-ICP-MS; the wet chemistry follows methods developed in Price et al. (2014) with modifications as follows: Following dissolution in concentrated $\mathrm{HF}$ and $\mathrm{HNO}_{3}, \mathrm{Sr}$ and $\mathrm{Pb}$ were purified by two passes through $100 \mu \mathrm{L}$ of Eichrom Sr resin $(25-50 \mu \mathrm{m})$, and $\mathrm{Nd}$ purified was purified from the wash of the Sr resin using a two-step method employing Eichrom TRU resin $(100-150 \mu \mathrm{m})$ followed by Eichrom LN-Spec resin $(50-100 \mu \mathrm{m})$. Total procedural blanks are $<200 \mathrm{pg}$ for $\mathrm{Sr},<50 \mathrm{pg}$ for $\mathrm{Nd}$, and $<120 \mathrm{pg}$ for $\mathrm{Pb}$.

2. A second batch of samples underwent $\mathrm{Sr}, \mathrm{Nd}$, and $\mathrm{Pb}$ chemical separations at UCSB as described above, with $\mathrm{Sr}$ and $\mathrm{Nd}$ isotopes analyzed on the UCSB TIMS. However, $\mathrm{Pb}$ isotopes were analyzed on the University of South Carolina MC-ICP-MS.

3. A third batch of samples, which included just the cpx separates for EX1702-D12-5 and EX1702-D7-5, underwent dissolution, chemical separations (for $\mathrm{Sr}, \mathrm{Nd}, \mathrm{Hf}$, and $\mathrm{Pb}$ ), and mass spectrometry at the University of South Carolina.

Further description of wet chemistry and mass spectrometry is provided below.

\section{Sr and Nd mass spectrometry at UCSB and Pb mass spectrometry at WHOI.}

$\mathrm{Sr}$ and Nd isotopes were analyzed on a Thermo Triton Plus TIMS mass spectrometer housed at UCSB. $500 \mathrm{ng}$ of $\mathrm{Sr}$ or Nd was loaded on outgassed, zone-refined Re (99.999\% purity, $\mathrm{H}$-Cross, USA) filaments. With the exception of the first ${ }^{87} \mathrm{Sr} /{ }^{86} \mathrm{Sr}$ analyses (EX1702-D12-5 clinopyroxene, EX1702-D7-5 clinopyroxene, EX1702-D11-1, EX1702-D3-2) and associated standards, which used a 33 picoamp gainboard but did not employ amplifier rotation, all other $\mathrm{Sr}$ and $\mathrm{Nd}$ isotopic analyses of samples, replicates, and associated standards employed amplifier rotation on $10^{11} \mathrm{ohm}$ amplifiers and a 3.3 picoamp gainboard. Gains were run with the start of a new barrel. Approximately $20 \%$ of analysis time was devoted to baselines: baselines are taken with each rotation of the amplifiers (i.e., because 5 amplifiers-cup pairs were used during analyses, 5 baselines were taken during each full amplifier rotation). Intensities were kept at approximately $3 \mathrm{~V}$ on mass 88 and $3 \mathrm{~V}$ on mass 144 during ${ }^{87} \mathrm{Sr} /{ }^{86} \mathrm{Sr}$ and ${ }^{143} \mathrm{Nd} /{ }^{144} \mathrm{Nd}$ analyses, respectively. $\mathrm{Sr}$ and $\mathrm{Nd}$ isotopes were corrected for mass bias assuming an exponential law and using canonical ${ }^{86} \mathrm{Sr} /{ }^{88} \mathrm{Sr}$ and ${ }^{146} \mathrm{Nd} /{ }^{144} \mathrm{Nd}$ ratios of 0.1194 and 0.7219 , respectively. Isobaric interferences from $\mathrm{Rb}$ and $\mathrm{Sm}$ were corrected by monitoring masses 85 and 147, but corrections to the ${ }^{87} \mathrm{Sr} /{ }^{86} \mathrm{Sr}$ and ${ }^{143} \mathrm{Nd} /{ }^{144} \mathrm{Nd}$ ratios were nominal. USGS reference materials (processed through all steps of wet chemistry and column chemistry with unknowns at UCSB) and sample unknowns were corrected for the offset between preferred and measured standard (NBS987 or JNdi) values with each barrel: preferred value for NBS987 ${ }^{87} \mathrm{Sr} /{ }^{86} \mathrm{Sr}$ is 0.710240 , and JNdi is 0.512099 (Garçon et al., 2018). On the UCSB Triton Plus the average ${ }^{87} \mathrm{Sr} /{ }^{86} \mathrm{Sr}$ and ${ }^{143} \mathrm{Nd} /{ }^{144} \mathrm{Nd}$ and long-term reproducibility, up to and including this study, of NBS987 and JNdi using amplifier rotation is $0.710246 \pm 0.000011(2 \mathrm{SD}, N=29)$ and, $0.512100 \pm 0.000004(2 \mathrm{SD}, N=27)$, respectively. The corresponding average ${ }^{87} \mathrm{Sr} /{ }^{86} \mathrm{Sr}$ and long-term reproducibility when analyzing NBS987 without amplifier rotation is $0.710244 \pm 0.000014$ (2SD, $N=39$ ).

We note that prior analyses of the AVON2/3 cruise samples from Rose (AVON2/3-66-1) and Malulu (AVON2/3-67-11), reported in Jackson et al. (2010), should be replaced by new analyses of these two samples shown in Table S1, for two reasons: 1) the previously published $\mathrm{Pb}$ isotopic analyses were made by TIMS without a spike addition to control for in-run mass fractionation and 2) these two samples exhibit significant alteration and acid leaching for the prior analyses may not have been sufficient to have removed alteration phases. We note that the new ${ }^{143} \mathrm{Nd} /{ }^{144} \mathrm{Nd}$ analysis for AVON2/3-67-11 (0.512982) shows significant disagreement with the prior analysis $(0.512796$, after correction to the JNdi reference frame use here by applying 
the La Jolla to JNdi conversion from Tanaka et al., 2000) made at WHOI in the year 2000 and reported by Jackson et al. (2010). In order to evaluate the accuracy of the new ${ }^{143} \mathrm{Nd} /{ }^{144} \mathrm{Nd}$ repository, including the original bag of crushed rock chips for this sample from which material was extracted for the 2000 analysis (see AVON2/3-67-11 rep1, rep2, and rep3 in Table S1); new batches of chips were prepared by separately crushing each aliquot, and the different aliquots of chips were leached and underwent wet chemistry and mass spectrometry during a separate session than the original analyses. The three replicate ${ }^{143} \mathrm{Nd} /{ }^{144} \mathrm{Nd}$ analyses $(0.512982,0.512980$, and 0.512981 ) show excellent agreement with the new ${ }^{143} \mathrm{Nd} /{ }^{144} \mathrm{Nd}$ result, confirming its accuracy. We note that the new analyses of $\mathrm{Sr}$ and $\mathrm{Pb}$ isotopes for this sample are similar to the published data for this sample reported in Jackson et al. (2010).

Using the $\mathrm{Pb}$ fractions purified at $\mathrm{UCSB}, \mathrm{Pb}$ isotopic analyses were carried out at the Woods Hole Oceanographic Institution using the Thermo Neptune MC-ICP-MS housed there (Hart and Blusztajn, 2006). Fractionation correction was made by Tl-addition assuming an exponential fractionation law (White et al., 2001). Samples and an aliquot of AGV-2 (processed through all steps of column chemistry and mass spectrometry with the samples) were corrected for the offset between preferred (i.e., values from Eisele et al., 2003) and measured ratios of NBS981.

For a different subset of samples (specified in Table S2), Pb fractions purified at UCSB were carried out at the University of South Carolina on Thermo Neptune MC-ICP-MS housed there. The samples, together with an aliquot of BCR-2 (processed through all steps of column chemistry and mass spectrometry with the samples) were corrected for the offset between preferred (i.e., values from Eisele et al., 2003) and measured ratios of NBS981.

\section{$\mathrm{Sr}, \mathrm{Nd}$, Hf and Pb isotopic and major and trace element concentrations on clinopyroxenes from} samples EX1702-D12-5 and EX1702-D7-5 at U. South Carolina.

Following leaching, visually fresh clinopyroxenes were picked under a binocular microscope. The clinopyroxene samples were then processed at the Center for Elemental Mass Spectrometry, University of South Carolina. Approximately 150-200 mg of sample was first leached (using the same protocol described above) and dissolved in Teflon distilled $\mathrm{HF}: \mathrm{HNO}_{3}$ (3:1) mixture on a hot plate for $\sim 3$ days, with frequent sonication. After drydown the samples were picked in $6 \mathrm{~N} \mathrm{HCl}$ with added boric acid in $10 \mathrm{~N} \mathrm{HCl}$ to complex fluorides, which increases yields in Hf chemistry (Frisby et al., 2016). Afterwards the samples were converted to nitrates. A small aliquot $(\sim 5 \%)$ was taken for $\mathrm{Sr}$ and $\mathrm{Nd}$ isotopes and the remainder was dried down with $\mathrm{HBr}$ for $\mathrm{Pb}$ and then $\mathrm{Hf}$ chemistry. A precisely determined aliquot of the dissolved clinopyroxene samples was pipetted from the solution and gravimetrically diluted for trace element analyses prior to the splitting of $\mathrm{Sr}-\mathrm{Nd}$ and $\mathrm{Pb}-\mathrm{Hf}$ fractions. Trace elements were then analyzed by ICP-MS with an aliquot of BHVO-1 on the Element2 following established methods for the lab (e.g. Frisby et al, 2016).

For the chemical separations, Sr was separated first on an Eichrom Sr-spec resin and the washes containing the rest of the elements were processed through an Eichrom TRU spec resin to concentrate the LREEs, and then on an Eichrom Ln-Resin to isolate $\mathrm{Nd}$ (Frisby et al, 2016). The $\mathrm{Pb}$ was separated on anion resin in $\mathrm{HBr}$ and $\mathrm{HCl}$ media, and the washes from that were processed for Hf following the method of Munker et al. (2001). An unleached BCR-2 powder was dissolved and processed through all steps of chemistry and mass spectrometry with sample unknowns. Total procedural blanks during the analytical session were $10 \mathrm{pg}$ for $\mathrm{Pb}, 180 \mathrm{pg}$ for 
$\mathrm{Sr},<10 \mathrm{pg}$ for $\mathrm{Nd}$, and $40 \mathrm{pg}$ for $\mathrm{Hf}$.

The isotopic compositions of $\mathrm{Sr}, \mathrm{Nd}, \mathrm{Pb}$, and $\mathrm{Hf}$ were measured on the Thermo Neptune housed at the University of South Carolina following methods provided in Beguelin et al., (2017). All samples were corrected for mass bias using the exponential law: $\mathrm{Pb}$ was corrected using the Tl addition method (White et al., 2001) ${ }^{87} \mathrm{Sr} /{ }^{86} \mathrm{Sr}$ was corrected using ${ }^{86} \mathrm{Sr} /{ }^{88} \mathrm{Sr}$ of $0.1194,{ }^{143} \mathrm{Nd} /{ }^{144} \mathrm{Nd}$ was corrected using ${ }^{146} \mathrm{Nd} /{ }^{144} \mathrm{Nd}$ of 0.7219 , and ${ }^{176} \mathrm{Hf} /{ }^{177} \mathrm{Hf}$ was corrected using ${ }^{179} \mathrm{Hf} /{ }^{177} \mathrm{Hf}$ of 0.7325 . All isotopic data on samples were corrected for the offset between measured and preferred standards using the following preferred values: SRM981 values from Eisele et al. (2003) $\left({ }^{206} \mathrm{~Pb} /{ }^{204} \mathrm{~Pb}=16.9409,{ }^{207} \mathrm{~Pb} /{ }^{204} \mathrm{~Pb}=15.4976\right.$, and $\left.{ }^{208} \mathrm{~Pb} / 204 \mathrm{~Pb}=36.7262\right)$; NBS987 ${ }^{87} \mathrm{Sr} /{ }^{86} \mathrm{Sr}$ value of 0.710240 ; JMC-475 ${ }^{176} \mathrm{Hf} /{ }^{177} \mathrm{Hf}$ value of 0.282160 ; JNdi ${ }^{143} \mathrm{Nd} /{ }^{144} \mathrm{Nd}$ value of 0.512099 (Garçon et al., 2018).

During the course of these measurements, reproducibility of ${ }^{87} \mathrm{Sr} /{ }^{86} \mathrm{Sr}$ on NBS987 was 22 ppm, of ${ }^{143} \mathrm{Nd} /{ }^{144} \mathrm{Nd}$ on JNdi-1 was $20 \mathrm{ppm}$, of ${ }^{176} \mathrm{Hf} /{ }^{177} \mathrm{Hf}$ on JMC-475 was $28 \mathrm{ppm}$, and $\mathrm{Pb}$ isotopic compositions on NBS981 were $62 \mathrm{ppm}$ on ${ }^{206} \mathrm{~Pb} /{ }^{204} \mathrm{~Pb}, 68 \mathrm{ppm}$ for ${ }^{207} \mathrm{~Pb} /{ }^{204} \mathrm{~Pb}$, and 80 $\mathrm{ppm}$ for ${ }^{208} \mathrm{~Pb} /{ }^{204} \mathrm{~Pb}$ (all $2 \mathrm{SE}$ ). An unleached BCR-2 powder was run together with the clinopyroxenes through all steps of column chemistry and mass spectrometry, and data are shown in Table S1.

Whole rock major and trace element analyses at Washington State University.

For samples EX1702-D7-2, EX1702-D3-2, and EX1702-D11-1, 10 to $20 \mathrm{~g}$ blocks of rock were cut with the rock saw, and care was taken to avoid visibly altered portions of rock. The blocks were cleaned with silicon carbide sand paper, and sonicated in MilliQ $\mathrm{H}_{2} \mathrm{O}$. Samples were crushed and then powdered in an agate shatterbox (with cleaning with silica between barrels) at the Geoanalytical lab at the Washington State University (WSU). Major and trace element concentrations were obtained at WSU by X-ray fluorescence (XRF) and ICP-MS. XRF and ICPMS methods, and evaluation of accuracy using international standards, are reported elsewhere (Knaack et al., 1994; Johnson et al., 1999), but summarized briefly here. The precision $(1 \sigma)$ for major elements in basalts by XRF is $0.11-0.33 \%(1 \sigma)$ of the amount present for $\mathrm{SiO}_{2}, \mathrm{Al}_{2} \mathrm{O}_{3}$, $\mathrm{TiO}_{2}, \mathrm{P}_{2} \mathrm{O}_{5}$ ) and $0.38-0.71 \%$ for other elements. Trace element precision of basalts by ICP-MS is $0.77-3.2 \%(1 \sigma)$ for trace elements except for U $(9.3 \%)$ and Th $(9.5 \%)$. An aliquot of the USGS reference material BCR-2 was analyzed as an unknown together with the basaltic unknowns, and the data are reported in Table S2. The new analysis of BCR-2 reported here is compared major and trace element compositions for this reference material reported in Jochum et al. (2016). Whole rock major and trace element analyses of the AVON2/3-67-1, AVON2/3-66-1, AVON2/3-65-18 and ALIA-DR129-05 were made following the same methods and data are reported in Jackson et al. (2010).

In situ major element analyses on glass by electron microprobe at UC Santa Barbara.

Glass was available for EX1702-D3-2. Sample chips were analyzed by electron microprobe at UC Santa Barbara using primary standards and following analytical conditions outlined in Jackson et al. (2015). The MORB basaltic secondary standard 519-4-1 was analyzed repeatedly throughout the analytical session. Major element compositions for sample unknown glass and the secondary standard (and previously published data on this secondary standard from Melson et al., 2002) are reported in Table S2.

In situ trace element analyses by LA-ICP-MS at Clermont-Ferrand. 
Trace element analyzes on the EX1702-D3-2 glass sample were made using a laser ablation ICP-MS system housed at Laboratoire Magmas et Volcans at Clermont-Ferrand. Analytical methods are outlined in Oulton et al. (2016) and Reinhart et al. (2018). Analyses were made using a Thermo Scientific Element XR ICP-MS coupled to a Resonetics M-50E 193 $\mathrm{nm}$ ArF excimer laser. ${ }^{43} \mathrm{Ca}$ was used as an internal standard. All surfaces were preablated (for $1 \mathrm{~s}$ at $10 \mathrm{~Hz}$ ) prior to analysis. Analyses of samples and standards used a $47 \mu \mathrm{m}$ laser spot, and the laser was fired with a $4 \mathrm{~Hz}$ repetition rate. Analyses were conducted over 80 second ablation periods, with 20 seconds of blank analysis (with the laser off) before samples analysis and (following a washout period) 20 seconds of blank analysis (again, with the laser off) after the analysis. Analyses were made in low resolution mode using triple mode with a $20 \%$ mass window and a $20 \mathrm{~ms}$ integration window. Acceleration voltage was scanned between magnet scans to ensure peak positions were maintained. Calibration curves were generated using NIST612 (Gagnon et al., 2008) and BCR-2 (Jochum et al., 2006) glass. Replicate analyses of a MORB glass, 519-4-1, were made throughout the analytical session to monitor precision and accuracy of analyses. The reproducibility of the trace element analyses was better than $10 \%$ (2RSD, N=8) for all elements except for Cs (44\%). Measured concentrations are compared with previously published analyses from Gale et al. (2013) in Table S2.

\section{Figure Captions}

Figure S1. Isotopic data for volcanoes in this study plotted with existing data for Macdonald and Arago volcanoes. The Rose atoll, Malulu seamount, and Dino seamount are all geochemically linked to the Macdonald hotspot, consistently grouping with Macdonald-type volcanoes. The Moki seamount falls into the region where the Macdonald and Arago isotope spaces overlap in all plots except for the plot of ${ }^{176} \mathrm{Hf} /{ }^{177} \mathrm{Hf}$ versus ${ }^{143} \mathrm{Nd} /{ }^{144} \mathrm{Nd}$ where it clearly links to Macdonald. A hotspot origin for Papatua cannot be determined as it consistently plots in the region of overlap between Macdonald and Arago isotope spaces. The Moki and Malulu isotopic data produced for this study are from clinopyroxene phenocrysts, as seawater alteration prevented the analysis of whole rock samples. New data also include pillow rim glass analyses from Rose atoll, whole rock data from Dino seamount, and new whole rock data on Rose and Malulu lavas. Whole rock data for the Rose atoll and the Malulu and Papatua seamounts was published by Jackson et al., 2010. All data not produced by this study was previously published and downloaded from Georoc (http://georoc.mpch681mainz.gwdg.de/georoc). Figure modified after Jackson et al. (2020).

Figure S2. Age-distance relationship for Arago and Macdonald volcanoes, with projected ages for interloper volcanoes Moki, Malulu, Dino, Papatua, and the Rose atoll for both Macdonald and Arago plume origin. Hawaiian hotspot data are shown for reference. This figure uses the great circle distances between current hotspot locations and a related volcano along the Wessel and Kroenke (2008) reconstructed trends. The volcanoes in this study plot in between the CAVL Macdonald volcanoes and the Macdonald hotspot-related Tokelau islands, suggesting that they bridge a geographic gap in Macdonald-type isotope geochemistry. Ages have been estimated for the five interloper volcanoes, based on the location of each volcano on the along-track distance trends, for both a Macdonald and Arago hotspot origin. Assuming Macdonald origin for all seamounts and the Rose atoll, Moki is $\sim 51$ Ma, Papatua is $\sim 46 \mathrm{Ma}$, Malulu is $\sim 44 \mathrm{Ma}$, Rose atoll is $\sim 43 \mathrm{Ma}$, and Dino is $\sim 39 \mathrm{Ma}$. Assuming Arago 
origin, Moki is $\sim 27 \mathrm{Ma}$, Papatua is $\sim 25 \mathrm{Ma}$, Malulu is $23 \mathrm{Ma}$, Rose atoll is $\sim 22 \mathrm{Ma}$, and Dino is $\sim 21 \mathrm{Ma}$. Age data used in this plot are provided in Jackson et al. (2020). Figure modified after Jackson et al. (2020).

Figure S3. Total alkali versus $\mathrm{SiO}_{2}$ diagram for whole rock lavas analyzed in this study. Whole rock data from other Cook-Austral volcanoes are shown for reference. The dashed line represents the boundary between the alkali (above the line) and tholeiitic (below the line) fields. The samples analyzed here plot broadly in the region defined by other volcanoes from the Cook-Austral volcanic lineament. Major elements are shown as normalized to $100 \%$ totals on a volatile-free basis. Major element data for the Malulu hyaloclastite (EX1702-12-5) are not shown, as only clinopyroxenes were analyzed.

Figure S4. Trace element spider diagrams for whole rock and clinopyroxene samples from study volcanoes. Trace element concentrations are normalized to pyrolite from McDonough and Sun (1995). Whole rocks are shown in the top panel, and clinopyroxenes in the lower panel.

\section{References Cited}

Beguelin, P., M. Bizimis, C. Beier, and S.Turner, 2017, Rift-plume interaction reveals multiple generations of recycled oceanic crust in Azores lavas. Geochimica et Cosmochimica Acta, v. 218, p. 132-152.

Eisele, J., Abouchami, W., Galer, S.J.G., and Hofmann, A.W., 2003, The 320 kyr $\mathrm{Pb}$ isotope evolution of Mauna Kea lavas recorded in the HSDP-2 drill core. Geochemistry, Geophysics, Geosystems, v. 4, 8710, doi:10.1029/2002GC000339.

Frisby, C., Bizimis, M. and Mallick, S., 2016, Hf-Nd isotope decoupling in bulk abyssal peridotites due to serpentinization. Chemical Geology, v. 440, p. 60-72.

Gagnon, J.E., Fryer, B.J., Samson, I.M., Williams-Jones, A.E., 2008, Quantitative analysis of silicate certified reference materials by LA-ICPMS with and without an internal standard. Journal of Analytic Atomic Spectrometry, v. 23, p. 1529-1537.

Gale, A., M. Laubier, S. Escrig, and C. H. Langmuir, 2013, Constraints on melting processes and plume-ridge interaction from comprehensive study of the FAMOUS and North Famous segments, Mid-Atlantic Ridge. Earth and Planetary Science Letters, v. 365, p. 209-220, doi:10.1016/801j.eps1.2013.01.022.

Garçon, M., Boyet, M., Carlson, R.W., Horan, M.F., Auclair, D., and Mock, T.D., 2018, Factors influencing the precision and accuracy of $\mathrm{Nd}$ isotope measurements by thermal ionization mass spectrometry. Chemical Geology, v. 476 p. 493-514.

Hart, S.R., and Blusztajn, J., 2006, Age and geochemistry of the mafic sills, ODP site 1276, Newfoundland margin. Chemical Geology, v. 235, p. 222-237.

630 Jackson, M.G., Hart, S.R., Konter, J.G., Koppers, A.A.P., Staudigel, H., Kurz, M.D., Blusztajn, 
J., and Sinton, J.M., 2010, The Samoan hotspot track on a "hotspot highway": Implications for mantle plumes and a deep Samoan mantle source. Geochemistry, Geophysics, Geosystems, v. 11, Q12009, doi:10.1029/2010GC003232.

Jackson, M.G., Koga, K.T., Price, A., Konter, J.G., Koppers, A.A.P., Finlayson, V.A., Konrad, K., Hauri, E.H., Kylander-Clark, A., Kelley, K.A., and Kendrick, M.A., 2015, Deeplydredged submarine HIMU glasses from the Tuvalu Islands, Polynesia: Implications for volatile budgets of recycled oceanic crust. Geochemistry, Geophysics, Geosystems, v. 16, p. 3210-3234, DOI: 10.1002/2015GC005966.

Jackson, M.G., Halldórsson, S.A., Price, A., Kurz, M.D., Konter, J.G., Koppers, A.A.P., Day, J.M.D., 2020, Contrasting old and young volcanism from Aitutaki, Cook Islands: Implications for the origins of the Cook-Austral volcanic chain. Journal of Petrology, egaa037, https://doi.org/10.1093/petrology/egaa037.

Jochum, K., Stoll, B., Herwig, K., Willbold, M., Hofmann, A., Amini, M., Aarburg, S., Abouchami, W., Hellebrand, E., Mocek, B., Raczek, I., Stracke, A., Alard, O., Bouman, C., Becker, S., Dücking, M., Brätz, H., Klemd, R., Bruin, D., Canil, D., Cornell, D., Hoog, C.-J., Dalpe, C., Danyushevsky, L., Eisenhauer, A., Gao, Y., Snow, J., Groschopf, N., Günther, D., Latkoczy, C., Guillong, M., Hauri, E., Höfer, H., Lahaye, Y., Horz, K., Jacob, D., Kasemann, S., Kent, A., Ludwig, T., Zack, T., Mason, P., Meixner, A., Rosner, M., Misawa, K., Nash, B., Pfänder, J., Premo, W., Sun, W., Tiepolo, M., Vannucci, R., Vennemann, T., Wayne, D., and Woodhead, J., 2006, MPIDING reference glasses for in situ microanalysis: new reference values for element concentrations and isotope ratios. Geochemistry, Geophysics, Geosystems, v. 7, Q02008.

Jochum, K., Weis, U., Schwager, B., Stoll, B., Wilson, S.A., Haug, G.H., Andreae, M.O., Enzweiler, J., 2016, Reference values following ISO guidelines for frequently requested rock reference materials. Geostandards and Geoanalytical Research, v. 40, p. 333-350.

Johnson, D.M., Hooper, P.R., and Conrey, R.M., 1999, XRF analysis of rocks and minerals for major and trace elements in a single low dilution Li-tetraborate fused bead. Advances in X-Ray Analysis, v. 41, p. 843-867.

Knaack, C.M., Cornelius, S.B., and Hooper, P.R., 1994, Trace element Analysis of rocks and minerals by ICP-MS. Open File Report, GeoAnalytical Lab. Washington State University, p. 10.

McDonough, W.F., Sun, S.S., 1995, The composition of the Earth. Chemical Geology, v. 120, p. 223-253.

Melson, W.G., O'Hearn, T., and Jarosewich, E., 2002, A data brief on the Smithsonian Abyssal Volcanic Glass Data File. Geochemistry, Geophysics, Geosystems, v. 3, p. 1-11, doi:10.1029/2001GC000249.

Munker, C., Weyer, S., Scherer, E. and Mezger, K., 2001, Separation of high field strength 
elements (Nb, Ta, Zr, Hf) and Lu from rock samples for MC-ICPMS measurements. Geochemistry, Geophysics, Geosystems, v. 2, p. 1064, doi:10/1029:2001GC000183.

Oulton, J., Humayun, M., Fedkin, A., and Grossman, L., 2016, Chemical evidence for differentiation, evaporation and recondensation from silicate clasts in Gujba. Geochimica et Cosmochimica Acta, v. 177, p. 254-274.

Price, A.A., Jackson, M.G., Blichert-Toft, J., Hall, P.S., Sinton, J.M., Kurz, M.D., and Blusztajn, J., 2014, Evidence for a broadly distributed Samoan-plume signature in the northern Lau and North Fiji Basins. Geochemistry, Geophysics, Geosystems, v. 15, p. 986-1008, doi: 10.1002/2013GC005061.

Price, A.A., Jackson, M.G., Blichert-Toft, J., Blusztajn, J., Conatser, C.S., Konter, J.G., Koppers, A.A.P., and Kurz, M.D., 2016, Geochemical evidence in the Northeast Lau Basin for subduction of the Cook-Austral volcanic chain in the Tonga Trench. Geochemistry, Geophysics, Geosystems, v. 17, p. 1694-1724, doi:10.1002/2015GC006237.

Reinhard, A.A., Jackson, M.G., Koornneef, J.M., Rose-Koga, E.F., Blusztajn, J., Konter, J.G., Koga, K.T., Wallace, P.J., Harvey, J., 2018, Sr and Nd isotopic compositions of individual olivine-hosted melt inclusions from Hawai'I and Samoa: Implications for the origin of isotopic heterogeneity in melt inclusions from OIB lavas. Chemical Geology, v. 495 , p. $36-49$.

Tanaka, T., Togashi, S., Kamioka, H., Amakawa, H., Kagami, H., Hamamoto, T., Yuhara, M., Orihashi, Y., Yoneda, S., Shimizu, H., Kunimaru, T., Takahashi, K., Yanagi, T., Nakano, T., Fujimaki, H., Shinjo, R., Asahara, Y., Tanimizu, M., and Dragusanu, C., 2000, JNdi1: A neodymium isotopic reference in consistency with LaJolla neodymium. Chemical Geology, v. 168, p. 279-281.

Weis, D., Kieffer, B., Maerschalk, C., Barling, J., de Jong, J.. Williams, G.A., Hanano, D., Pretorius, W., Mattielli, N., Scoates, J.A., Goolaerts, A., Friedman, R.M., Mahoney, B.J., 2006, High-precision isotopic characterization of USGS reference materials by TIMS and MC-ICP-MS. Geochemistry, Geophysics, Geosystems, v. 7, Q08006.

Weis, D., Kieffer, B., Hanano, D., Silva, I.N., Barling, J., Pretorius, W., Maerschalk, C., Matielli, N., 2007, Hf isotope compositions of U.S. Geological Survey reference materials. Geochemistry, Geophysics, Geosystems, v. 8, Q06006.

Wessel, P., and Kroenke, L.W., 2008, Pacific absolute plate motion since 145Ma: an assessment of the fixed hot spot hypothesis. Journal of Geophysical Research, v.113, B06101. https://doi.org/10.1029/2007JB005499.

White, W.M., Albarede, F. and Telouk, P., 2000, High-precision analysis of Pb isotope ratios by multi-collector ICP-MS. Chemical Geology, v. 167, p. 257-270. 


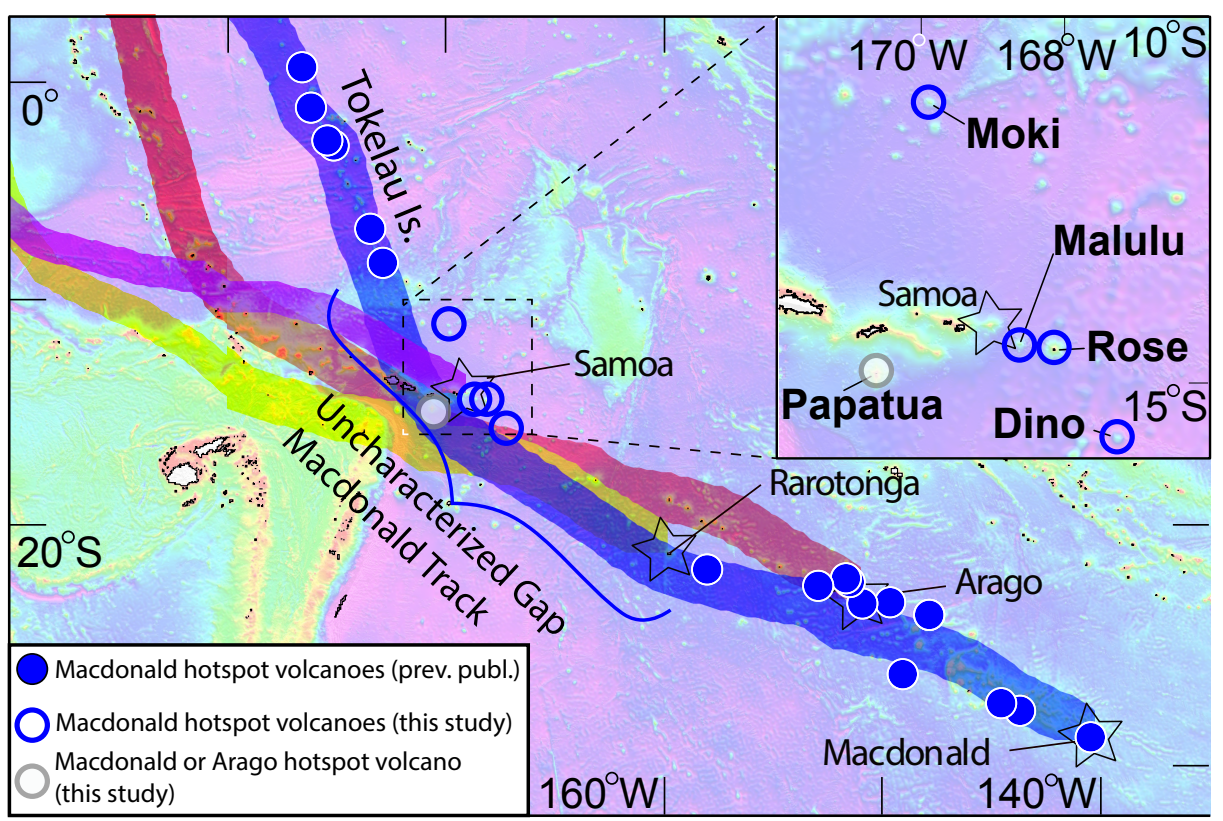

Figure 1 


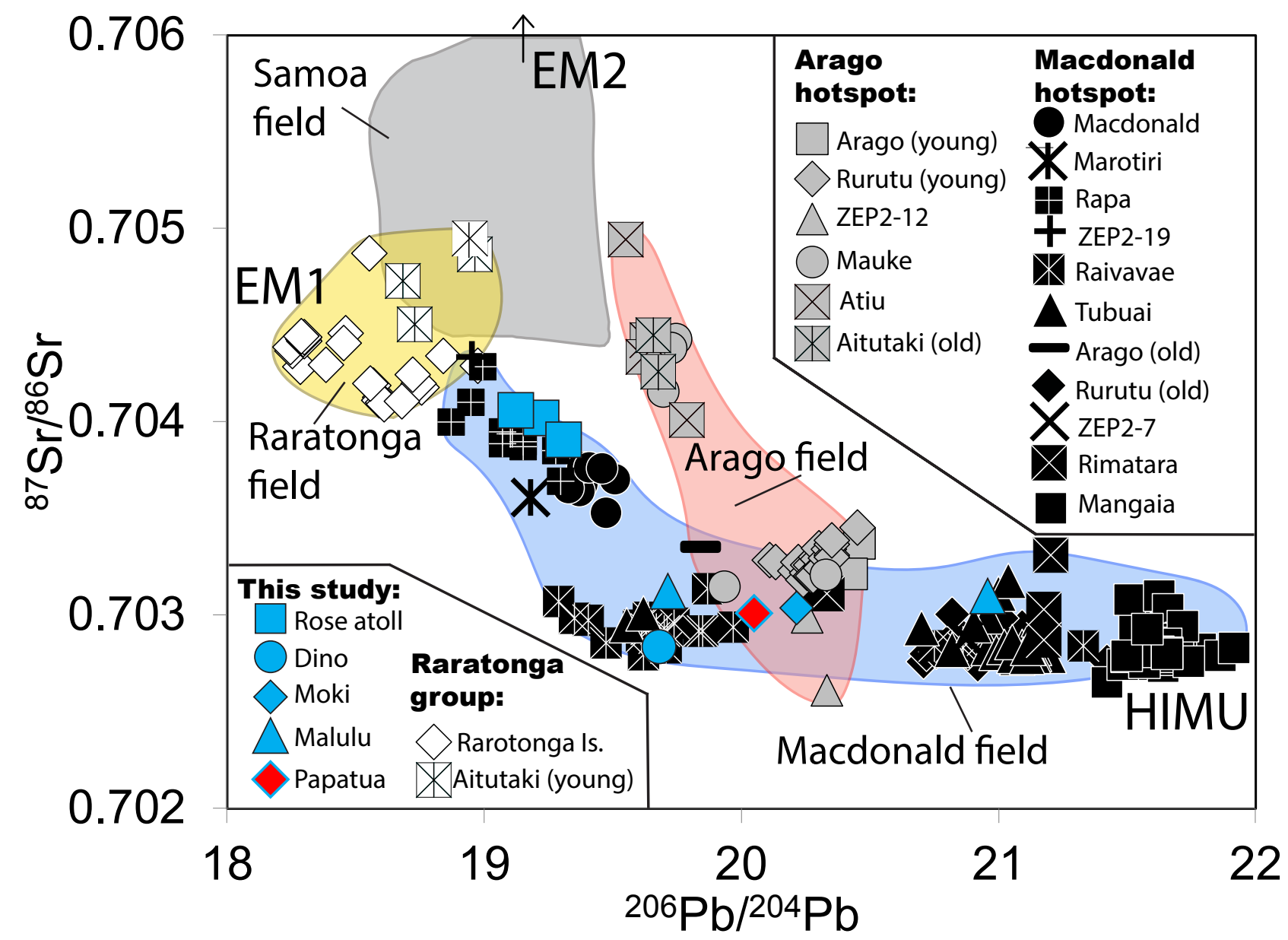

Figure 2 


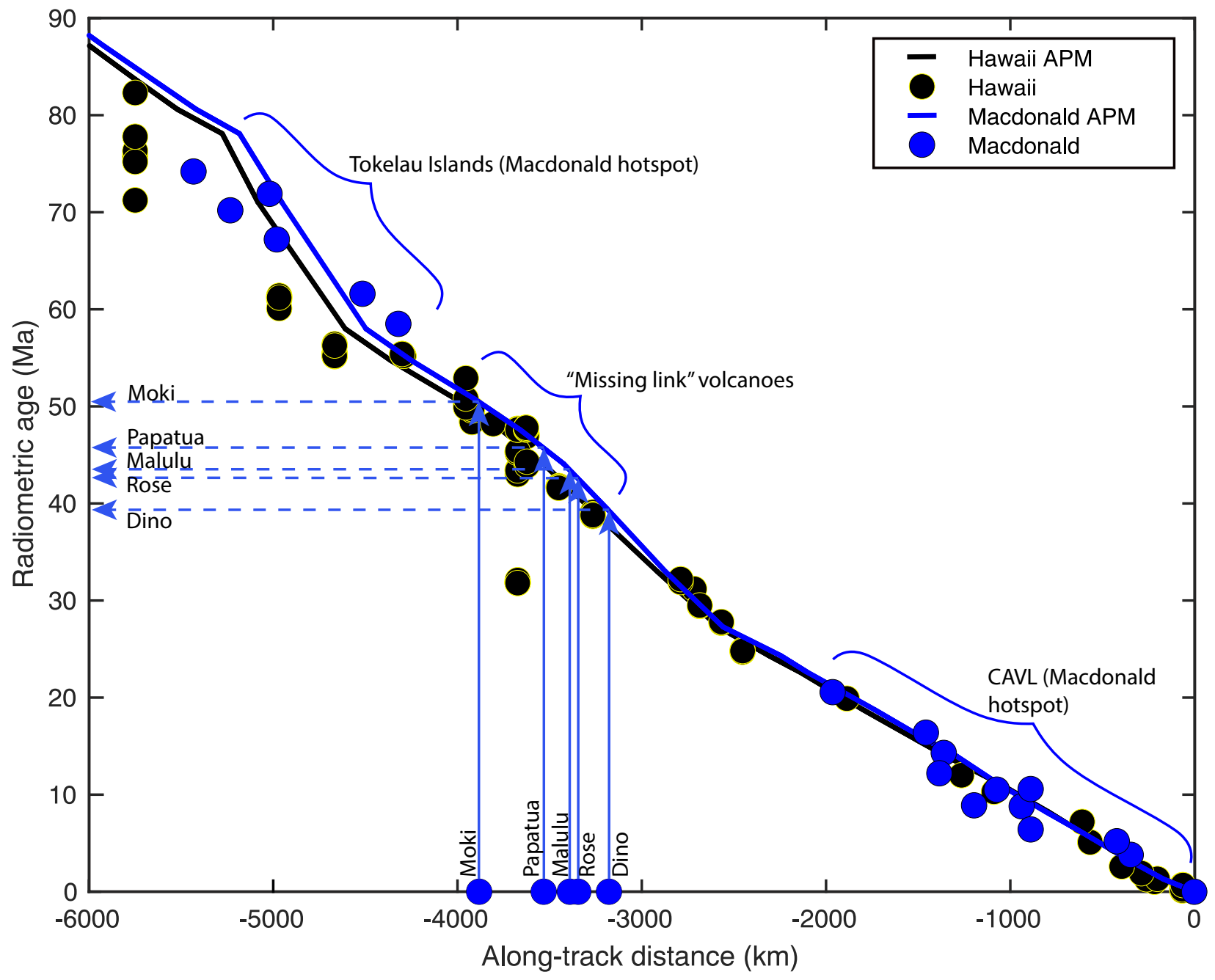

Figure 3 
Table S1. Radiogenic isotopic compositions for whole rocks, glass, and clinopyroxene separates from non-Samoan "interloper" seamounts in the Samoan region. ${ }^{1}$

\begin{tabular}{|c|c|c|c|c|c|c|c|c|c|c|c|c|c|c|c|c|}
\hline Sample ID & Volcano name & Material analyzed & Latitude & Longitude & ${ }^{87} \mathrm{Sr}^{86}{ }^{86} \mathrm{Sr}$ & $2 \mathrm{SE}$ & ${ }^{143} \mathrm{Nd} /{ }^{144} \mathrm{Nd}$ & 2SE & ${ }^{176} \mathrm{Hf} / /^{177} \mathrm{Hf}$ & 2SE & ${ }^{206} \mathbf{P b} /{ }^{204} \mathbf{P b}$ & 2SE & ${ }^{207} \mathrm{~Pb} /{ }^{204} \mathrm{~Pb}$ & 2SE & ${ }^{208} \mathbf{P b} /{ }^{204} \mathbf{P b}$ & $2 \mathrm{SE}$ \\
\hline EX1702-D7-2 ${ }^{2}$ & Moki smt. & cpx & -11.1682 & -169.8922 & 0.703037 & 0.000005 & 0.512908 & 0.000005 & 0.282922 & 0.000003 & 20.2209 & 0.0016 & 15.6205 & 0.0012 & 40.0478 & 0.0031 \\
\hline EX1702-D7-2 гер ${ }^{3}$ & Moki smt. & cpx & -11.1682 & -169.8922 & 0.703034 & 0.000005 & 0.512911 & 0.000004 & & & & & & & & \\
\hline EX1702-D11-1 ${ }^{3}$ & Smt D (Dino) & whole rock & -15.7331 & -167.2646 & 0.702872 & 0.000009 & 0.512989 & 0.000005 & & & 19.6917 & 0.0029 & 15.6201 & 0.0025 & 39.2270 & 0.0059 \\
\hline EX1702-D11-1 rep ${ }^{4}$ & Smt D (Dino) & whole rock & -15.7331 & -167.2646 & 0.702795 & 0.000003 & 0.512985 & 0.000004 & & & 19.7050 & 0.0078 & 15.6162 & 0.0069 & 39.3336 & 0.0198 \\
\hline EX1702-D3-2 ${ }^{4}$ & Rose atoll & glass & -14.5377 & -168.0799 & 0.704014 & 0.000003 & 0.512817 & 0.000003 & & & 19.2401 & 0.0005 & 15.6203 & 0.0005 & 39.0252 & 0.0017 \\
\hline AVON2/3-D66-1 ${ }^{3}$ & Rose atoll & whole rock & -14.6433 & -168.1956 & 0.704085 & 0.000006 & 0.512798 & 0.000003 & & & 19.1025 & 0.0058 & 15.5980 & 0.0047 & 38.9144 & 0.0107 \\
\hline AVON2/3-D $66-1{ }^{5}$ & Rose atoll & whole rock & -14.6433 & -168.1956 & 0.704137 & & 0.512796 & & & & 19.14 & & 15.62 & & 38.98 & \\
\hline AVON2/3-D65-18 5 & Rose atoll & whole rock & -14.4890 & -168.2609 & 0.703923 & & 0.512846 & & & & 19.32 & & 15.61 & & 39.1615 & \\
\hline EX1702-D12-5 ${ }^{2}$ & Malulu smt & cpx & -14.4689 & -168.6389 & 0.703121 & 0.000005 & 0.512979 & 0.000003 & 0.283051 & 0.000004 & 19.7237 & 0.0007 & 15.5812 & 0.0007 & 39.4479 & 0.0018 \\
\hline EX1702-D12-5 rep ${ }^{4}$ & Malulu smt & cpx & -14.4689 & -168.6389 & 0.703101 & 0.000003 & 0.512982 & 0.000002 & & & 19.7483 & 0.0059 & 15.5877 & 0.0056 & 39.4271 & 0.0162 \\
\hline AVON2/3-D67-11 ${ }^{3}$ & Malulu smt & whole rock & -14.4988 & -168.6631 & 0.703096 & 0.000006 & 0.512982 & 0.000003 & & & & & & & & \\
\hline AVON2/3-D67-11 rep1 ${ }^{3}$ & Malulu smt & whole rock & -14.4988 & -168.6631 & 0.703100 & 0.000007 & 0.512982 & 0.000003 & & & 20.9563 & 0.0024 & 15.6535 & 0.0017 & 40.9142 & 0.0048 \\
\hline AVON2/3-D67-11 rep2 ${ }^{3}$ & Malulu smt & whole rock & -14.4988 & -168.6631 & 0.703108 & 0.000006 & 0.512980 & 0.000003 & & & & & & & & \\
\hline AVON2/3-D67-11 rep3 ${ }^{3}$ & Malulu smt & whole rock & -14.4988 & -168.6631 & 0.703102 & 0.000007 & 0.512981 & 0.000003 & & & & & & & & \\
\hline AVON2/3-D67-11 ${ }^{5}$ & Malulu smt & whole rock & -14.4988 & -168.6631 & 0.703108 & & $0.512765^{7}$ & & & & 20.96 & & 15.66 & & 40.71 & \\
\hline ALIA-DR 129-0 ${ }^{6}$ & Papatua smt & whole rock & -14.9705 & -170.5900 & 0.703009 & & 0.512976 & & & & 20.0614 & & 15.6561 & & 39.6569 & \\
\hline${\mathrm{BCR}-2^{2}}^{2}$ & & powder & & & 0.705010 & 0.000004 & 0.512623 & 0.000010 & 0.282873 & 0.000003 & 18.7561 & 0.0026 & 15.6210 & 0.0032 & 38.7311 & 0.0035 \\
\hline${\mathrm{BCR}-2^{3}}^{3}$ & & powder & & & 0.705007 & 0.000006 & 0.512621 & 0.000002 & & & & & & & & \\
\hline $\mathrm{BCR}-2^{3}$ & & powder & & & 0.705003 & 0.000006 & 0.512620 & 0.000002 & & & 18.7543 & 0.0004 & 15.6188 & 0.0004 & 38.7162 & 0.0013 \\
\hline $\mathrm{BCR}-2^{3}$ & & powder & & & 0.705006 & 0.000006 & 0.512625 & 0.000003 & & & 18.7415 & 0.0004 & 15.6093 & 0.0004 & 38.6795 & 0.0013 \\
\hline BCR-2 published (Weis et & $6,2007)^{1}$ & powder & & & 0.705005 & 0.000010 & 0.512621 & 0.000012 & 0.282870 & 0.000008 & 18.7533 & 0.0195 & 15.6262 & 0.0040 & 38.7282 & 0.0405 \\
\hline $\mathrm{AGV}_{-2}{ }^{4}$ & & powder & & & 0.703981 & 0.000004 & 0.512776 & 0.000002 & & & 18.8704 & 0.0010 & 15.6215 & 0.0009 & 38.5527 & 0.0025 \\
\hline AGV-2 published (Weis et & $6,2007)^{1}$ & powder & & & 0.703973 & 0.000009 & 0.512775 & 0.000010 & & & 18.8692 & 0.0063 & 15.6186 & 0.0071 & 38.5488 & 0.0135 \\
\hline
\end{tabular}

1. All data in the table are reported relative to the following international standard values: Nd isotopes are corrected to JNdi value of 0.512099 (Garcon et al., 2018), Sr isotopic data to an NBS 987 value of 0.710240 , Pb isotopic compositions are corrected to the NIST 981 values of Eisele et al. (2003) (16.9409, 15.4976, 36.7262), and Hf isotopic data are corrected to the JMC-475 of 0.282160. For the data from Weis et al (2006, 2007), Nd isotopic compositions are renormalized to a JNdi equivalent value of 0.512099 using Tanaka et al.'s (2000) La Jolla to JNdi-1 conversion, and their Pb isotopic data are renormalize to the NBS 81 values from Eisele et al. (2003), and only teflon data are shown for the Hf isotopic dataset. Italicized as 2SD of multiple analyses (all other errors in the table are 2SE), except for the BCR analysis at University of South Carolina (which is the 2SD of 5 analyses of the same BCR-2).

2. All leaching, wet chemistry (sample dissolutions and chemical separations) and mass spectrometry (all using MC-ICP-MS) for $\mathrm{Sr}, \mathrm{Nd}, \mathrm{Pb}$ and $\mathrm{Hf}$ isotopes completed at U. South Carolina.

3. Leaching and wet chemistry (sample dissolutions and chemical separations) for Sr, Nd, and Pb completed at UCSB. Sr and Nd mass spectrometry completed on UCSB TIMS, and Pb mass spectrometry (if any) completed on U. South Carolina MC-ICP-MS.

4. Leaching and wet chemistry (sample dissolutions and chemical separations) for $\mathrm{Sr}, \mathrm{Nd}$, and Pb completed at UCSB. Sr and Nd mass spectrometry completed on UCSB TIMS, and Pb mass spectrometry (if any) completed on WHOI MC-ICP-MS.

5. Leaching and wet chemistry (sample dissolutions and chemical separations) and mass spectrometry for $\mathrm{Sr}$, $\mathrm{Nd}$, and $\mathrm{Pb}$ completed on WHOI TIMS (data published in Jackson et al., 2010).

6. Leaching and wet chemistry (sample dissolutions and chemical separations) and mass spectrometry for Sr, Nd, and Pb completed on WHOI MC-ICP-MS (data published in Jackson et al., 2010).
7. This result is superceded by new analyses of this sample made at UCSB (also presented in this table). 


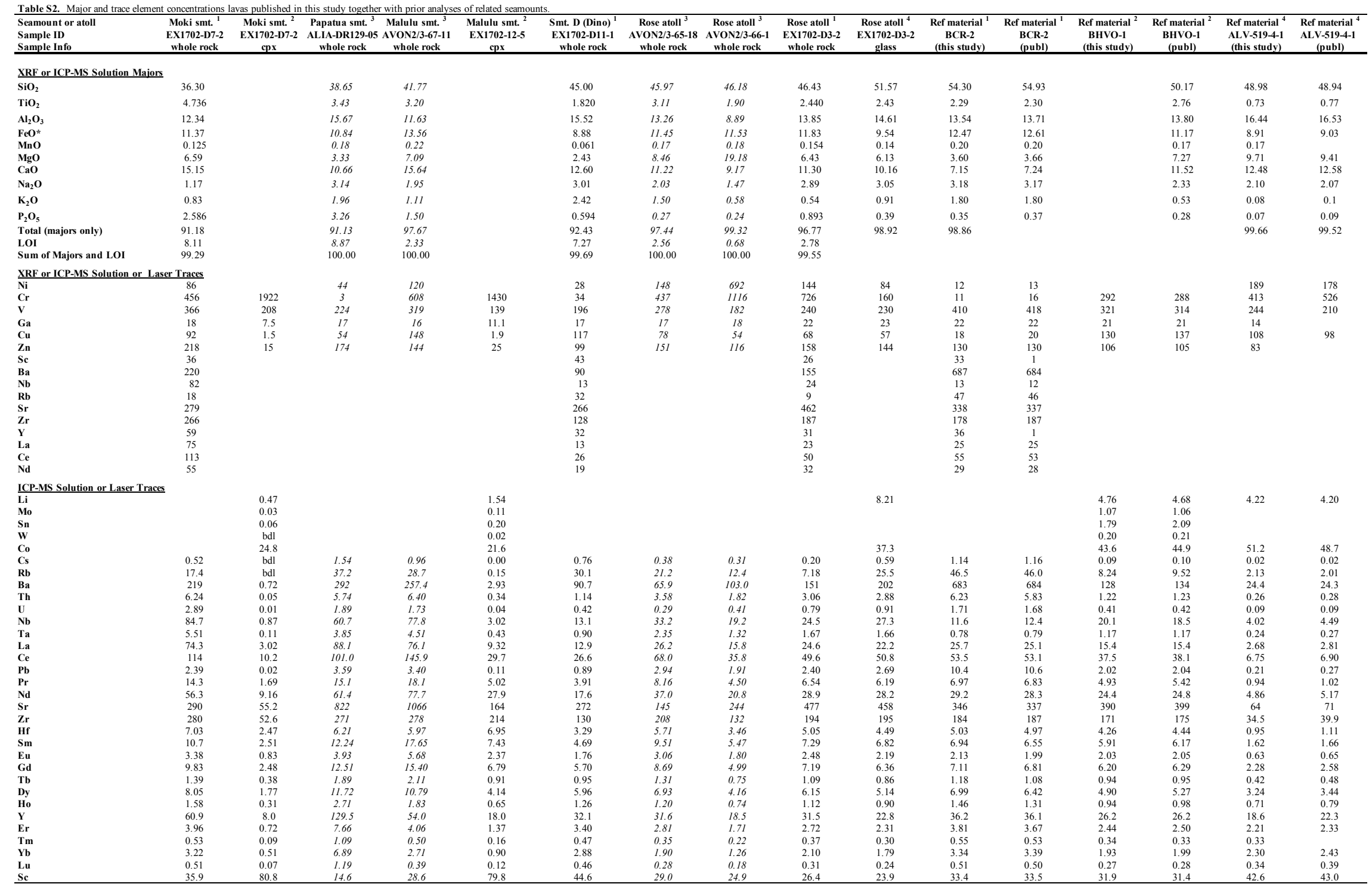

1. For whole rock samples EX1702-D7-2, EX1702-D11-1, and EX1702-D3-2, major elements and a subset of trace elements analyzed by XRF, and some of these trace elements and an additional set of trace elements were analyzed by solution ICP-MS. A BCR-2 reference

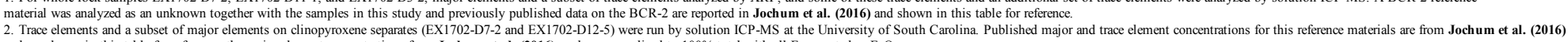

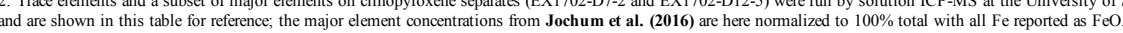

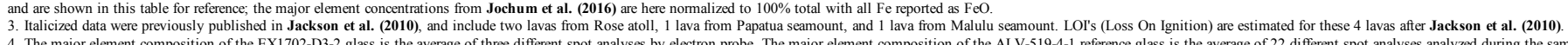

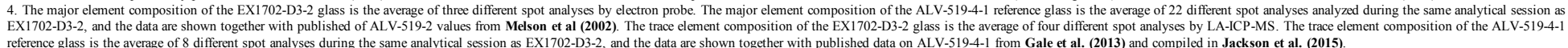



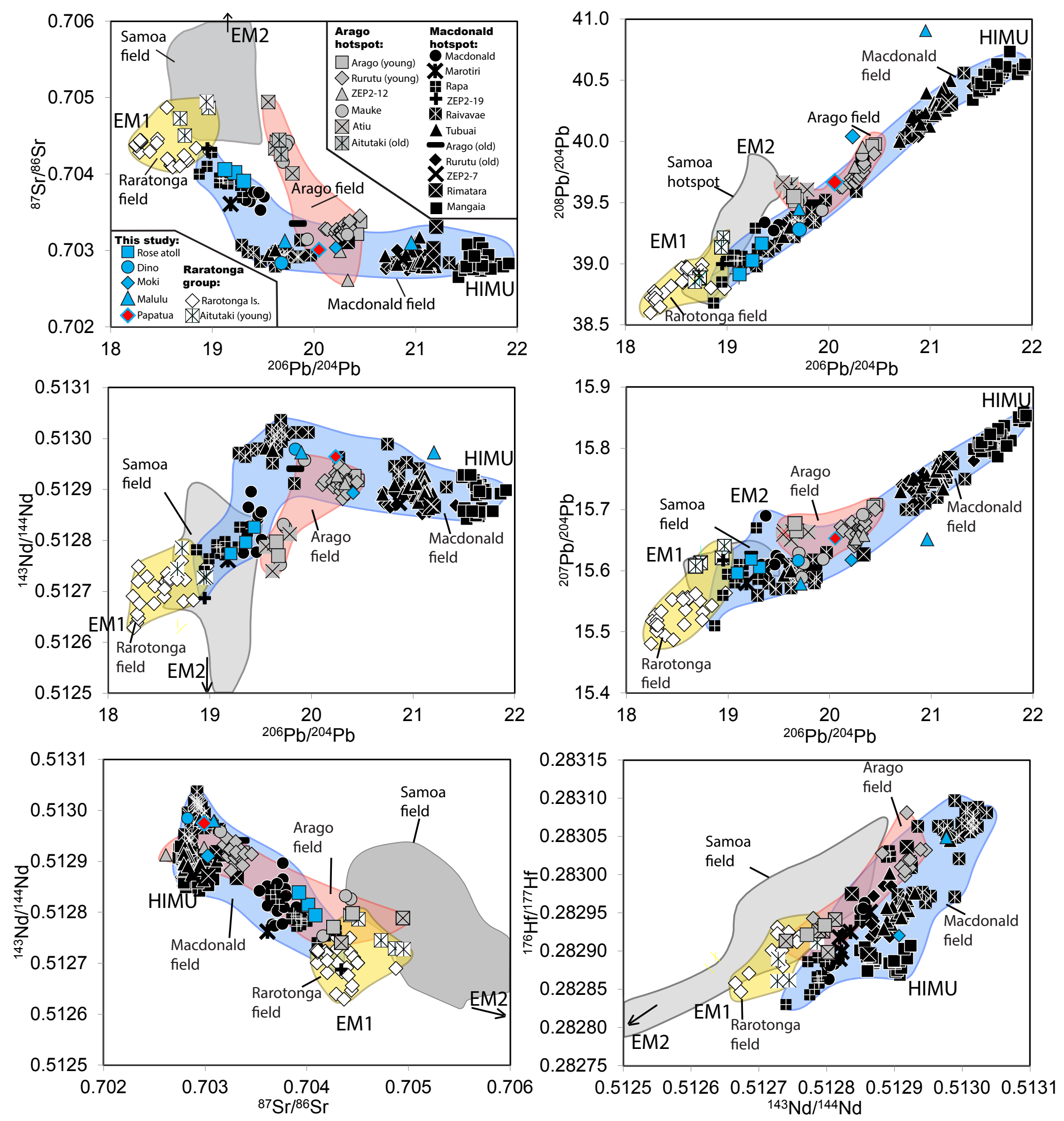

Figure S1 


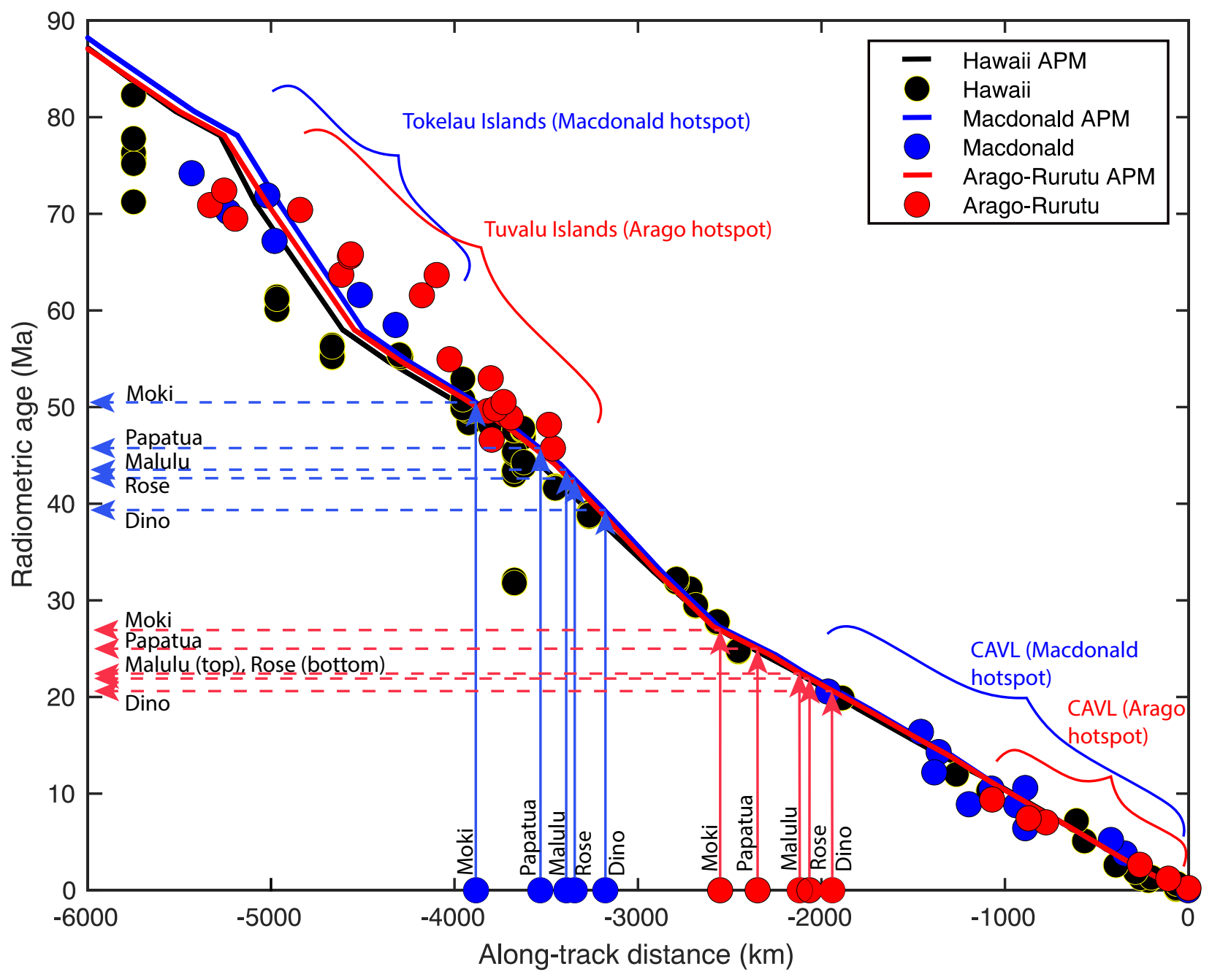

Figure S2 


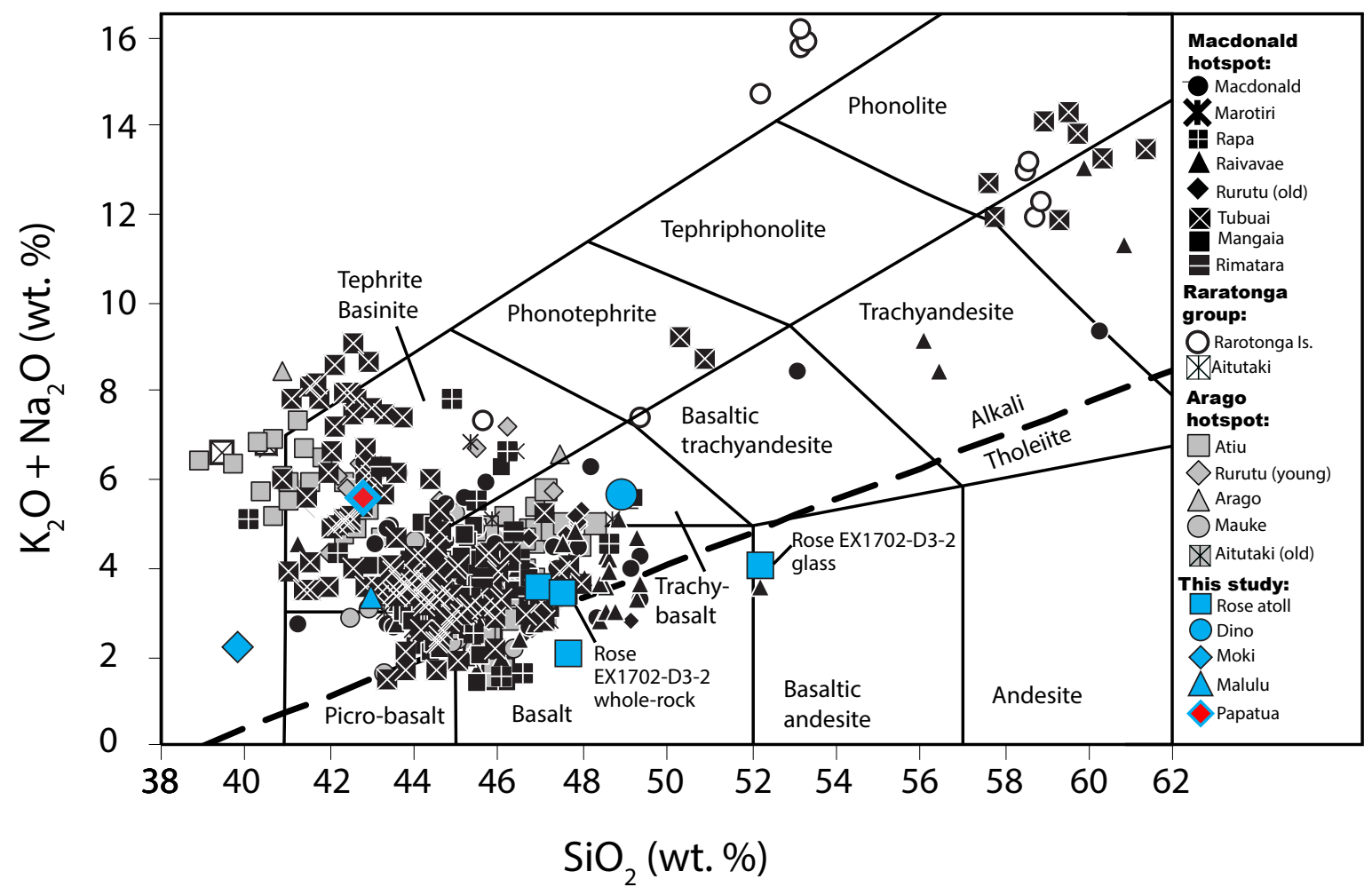

Figure S3 


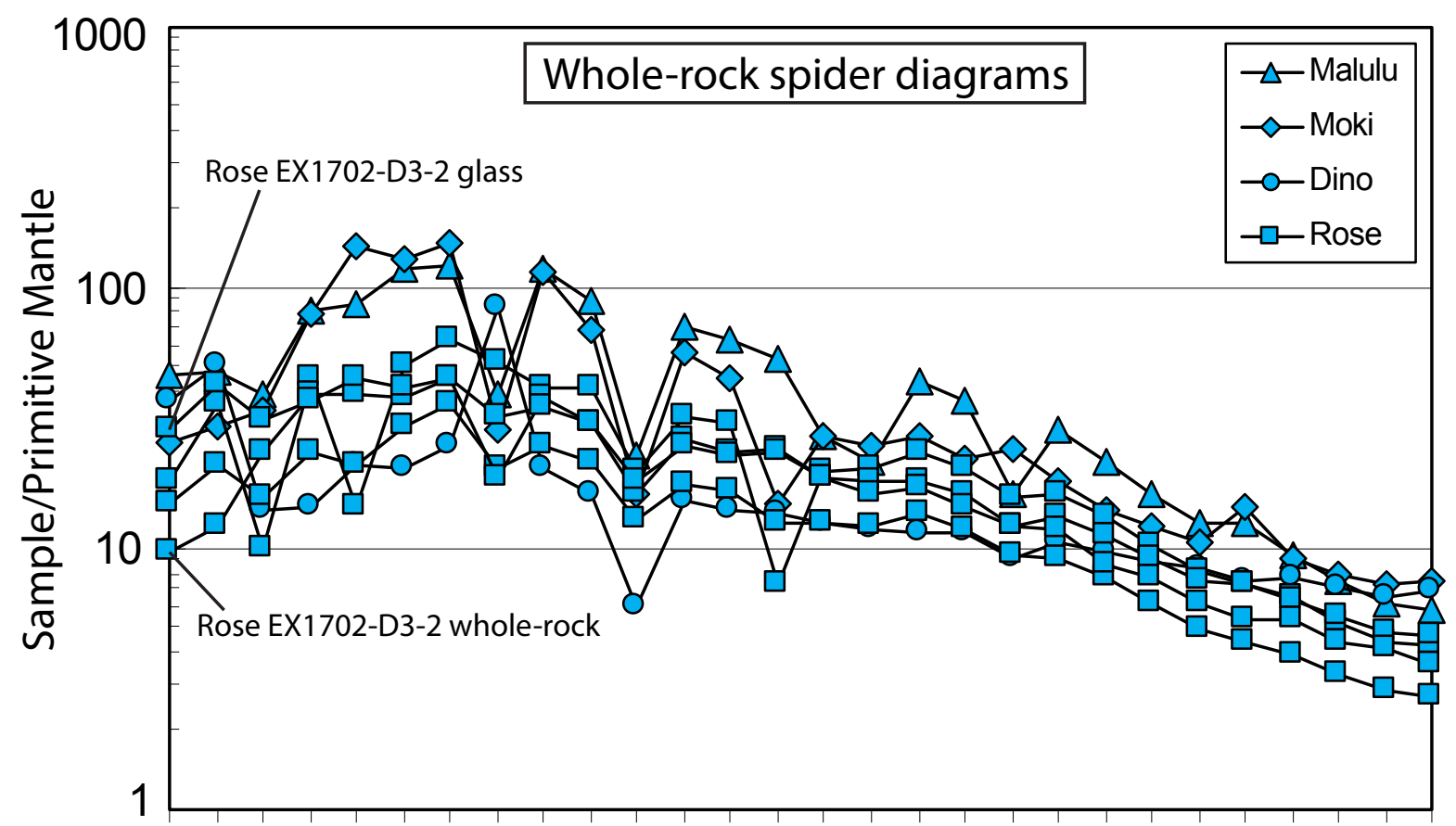

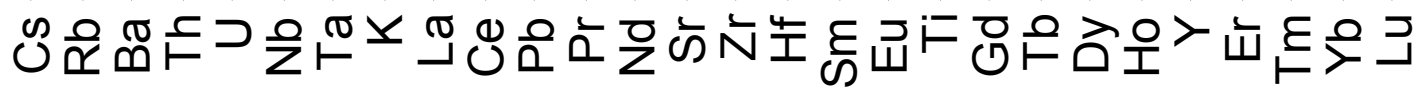

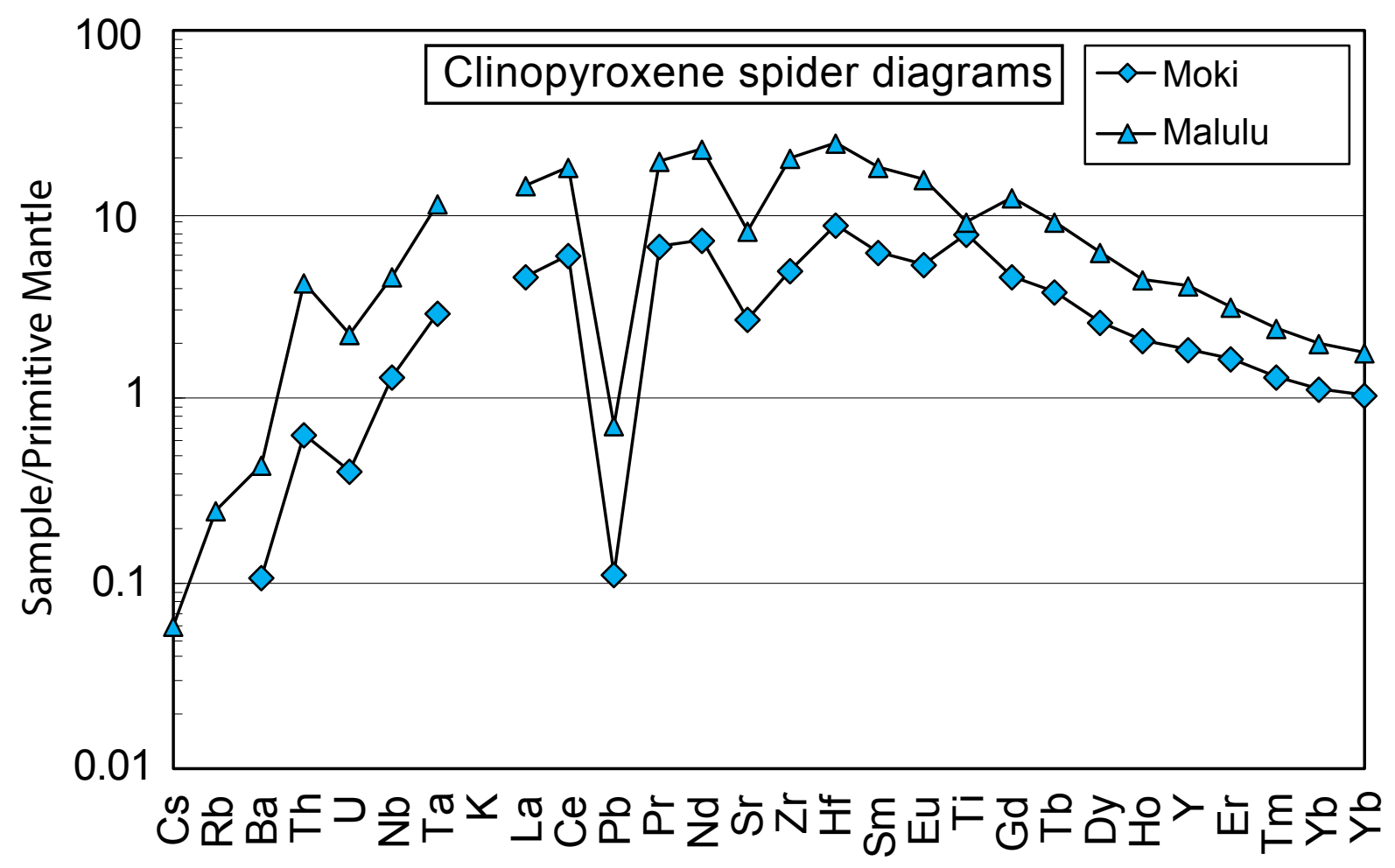

Figure S4 